
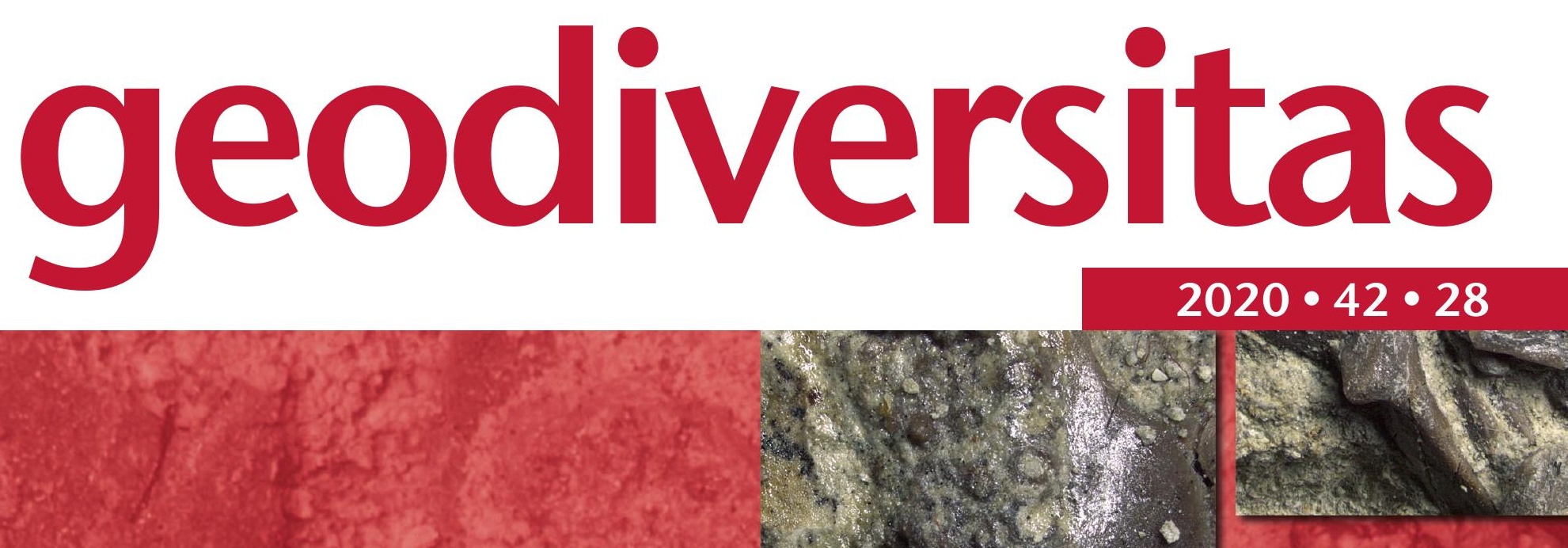

\title{
Revision of the cranial anatomy of Ophisaurus acuminatus Jörg, 1965 (Anguimorpha, Anguidae) from the late Milocene of Germany
}

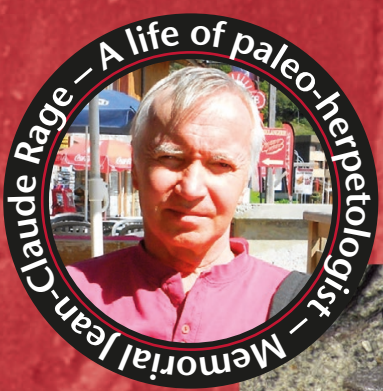

Jozef K MMBAARA \& Andrej ČERNANSKÝ
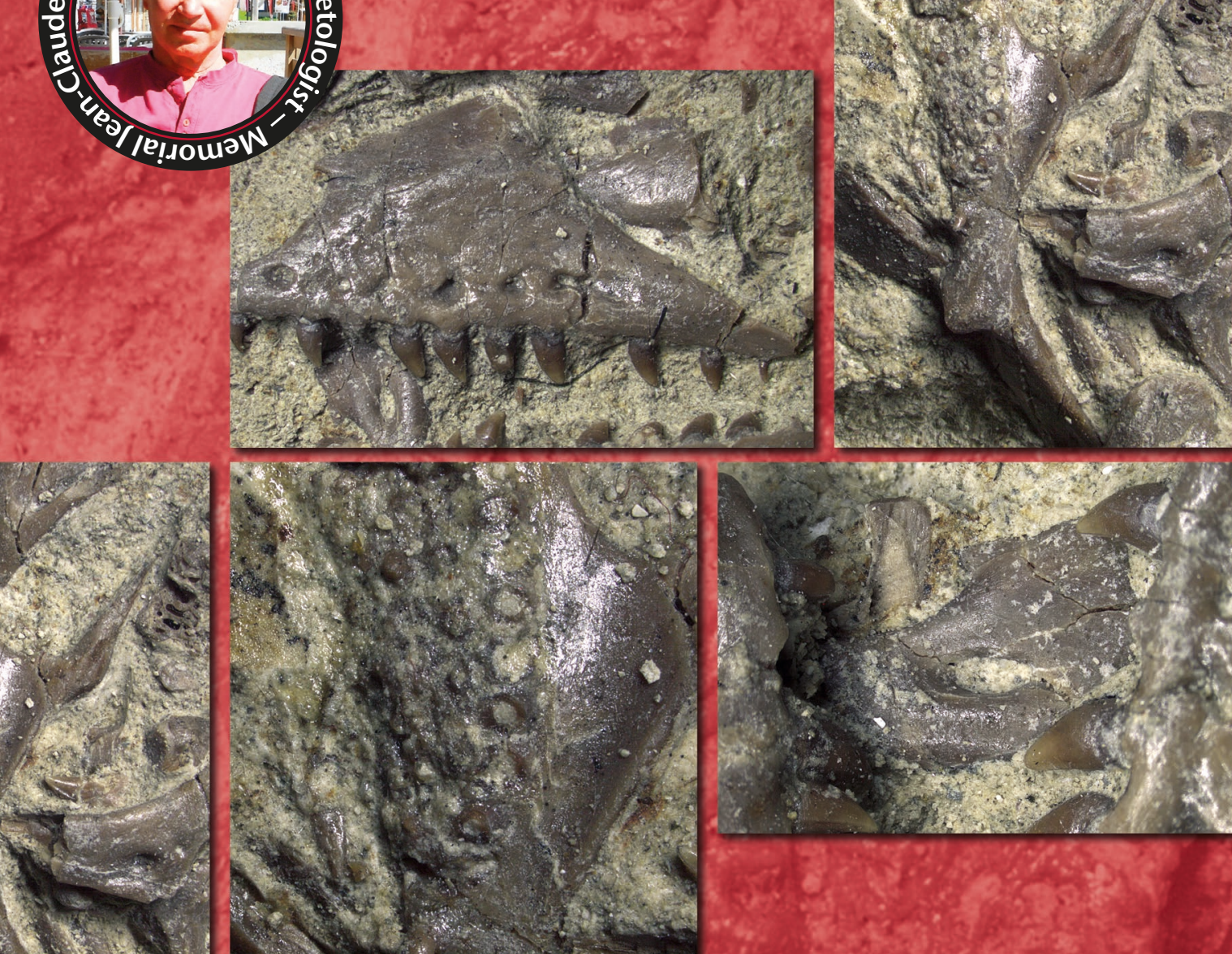

art $42(28)$ - Published on 3 December 2020 www.geodiversitas.com

PUBLICATIONS SCIENTIFIOUES 
DiReCteur de LA PUblication / PUBLICATION DIRECTOR : Bruno David,

Président du Muséum national d'Histoire naturelle

RÉDACTEUR EN CHEF / EDITOR-IN-CHIEF: Didier Merle

ASSISTANT DE RÉDACTION / ASSISTANT EDITOR: Emmanuel Côtez (geodiv@mnhn.fr)

Mise EN PAGE / PAGE LAYOUT: Emmanuel Côtez

COMITÉ SCIENTIFIQUE / SCIENTIFIC BOARD:

Christine Argot (Muséum national d'Histoire naturelle, Paris)

Beatrix Azanza (Museo Nacional de Ciencias Naturales, Madrid)

Raymond L. Bernor (Howard University, Washington DC)

Alain Blieck (chercheur CNRS retraité, Haubourdin)

Henning Blom (Uppsala University)

Jean Broutin (Sorbonne Université, Paris, retraité)

Gaël Clément (Muséum national d'Histoire naturelle, Paris)

Ted Daeschler (Academy of Natural Sciences, Philadelphie)

Bruno David (Muséum national d'Histoire naturelle, Paris)

Gregory D. Edgecombe (The Natural History Museum, Londres)

Ursula Göhlich (Natural History Museum Vienna)

Jin Meng (American Museum of Natural History, New York)

Brigitte Meyer-Berthaud (CIRAD, Montpellier)

Zhu Min (Chinese Academy of Sciences, Pékin)

Isabelle Rouget (Muséum national d'Histoire naturelle, Paris)

Sevket Sen (Muséum national d'Histoire naturelle, Paris, retraité)

Stanislav Štamberg (Museum of Eastern Bohemia, Hradec Králové)

Paul Taylor (The Natural History Museum, Londres, retraité)

COUVERTURE / COVER:

Réalisée à partir des Figures de l'article/Made from the Figures of the article.

Geodiversitas est indexé dans / Geodiversitas is indexed in:

- Science Citation Index Expanded (SciSearch ${ }^{\circledR}$ )

- ISI Alerting Services ${ }^{\circledR}$

- Current Contents ${ }^{\circledR}$ / Physical, Chemical, and Earth Sciences ${ }^{\circledR}$

- Scopus ${ }^{\circledR}$

Geodiversitas est distribué en version électronique par / Geodiversitas is distributed electronically by:

- BioOne ${ }^{\circledR}$ (http://www.bioone.org)

Les articles ainsi que les nouveautés nomenclaturales publiés dans Geodiversitas sont référencés par / Articles and nomenclatural novelties published in Geodiversitas are referenced by:

- ZooBank ${ }^{\circledR}$ (http://zoobank.org)

Geodiversitas est une revue en flux continu publiée par les Publications scientifiques du Muséum, Paris Geodiversitas is a fast track journal published by the Museum Science Press, Paris

Les Publications scientifiques du Muséum publient aussi / The Museum Science Press also publish: Adansonia, Zoosystema, Anthropozoologica, European Journal of Taxonomy, Naturae, Cryptogamie sous-sections Algologie, Bryologie, Mycologie, Comptes Rendus Palevol

Diffusion - Publications scientifiques Muséum national d'Histoire naturelle

CP $41-57$ rue Cuvier F-75231 Paris cedex 05 (France)

Tél. : 33 (0)1 40794805 / Fax: 33 (0)14079 3840

diff.pub@mnhn.fr / http://sciencepress.mnhn.fr

(C) Publications scientifiques du Muséum national d'Histoire naturelle, Paris, 2020

ISSN (imprimé / print): 1280-9659/ ISSN (électronique / electronic): 1638-9395 


\title{
Revision of the cranial anatomy of Ophisaurus acuminatus Jörg, 1965 (Anguimorpha, Anguidae) from the late Miocene of Germany
}

\author{
Jozef KLEMBARA \\ Andrej ČERŇANSKÝ \\ Department of Ecology, Laboratory of Evolutionary Biology, Comenius University in Bratislava, \\ Faculty of Natural Sciences, Ilkovičova 6, 84215 Bratislava (Slovakia) \\ jozef.klembara@uniba.sk
}

Submitted on 29 April 2019 | accepted on 16 October 2019 | published on 3 December 2020

urn:Isid:zoobank.org:pub:5138C1D3-0375-498E-B476-A41801F4E3AC

Klembara J. \& Čerňanský A. 2020. - Revision of the cranial anatomy of Ophisaurus acuminatus Jörg, 1965 (Anguimorpha, Anguidae) from the late Miocene of Germany, in Steyer J.-S., Augé M. L. \& Métais G. (eds), Memorial Jean-Claude Rage: A life of paleo-herpetologist. Geodiversitas 42 (28): 539-557. https://doi.org/10.5252/geodiversitas2020v42a28. http://geodiversitas.com/42/28

KEY WORDS

Squamata,

Anguinae,

Neogene,

Europe,
skull, osteoderms, morphology.

MOTS CLÉS Squamates,

anguinés,

Neogène,

Europe,

crâne,

ostéodermes, morphologie.

\begin{abstract}
The anguine species Ophisaurus acuminatus Jörg, 1965 is known on the basis of only one specimen consisting of skull bones and osteoderms from the late Miocene (MN 9) Höwenegg/Hegau locality in Germany. Since its first description, several other new species of Ophisaurus Daudin, 1803 have been described from various Miocene localities in Europe. The diagnoses of these new species are based mostly on characters on the parietal and partially frontal bones. Although most of the cranial elements of $O$. acuminatus are well preserved, its parietal is absent. The knowledge of the detailed anatomy of this anguine species is crucial for the understanding of its interrelationship within the genus Ophisaurus. For our re-study of this specimen we used a high-resolution X-ray microcomputed tomography. The application of this method enabled: 1) to reveal the anatomy of not visible portions of the previously described bones; 2) to discover the bones completely or almost completely embedded in the sediment; and 3) to identify previously not determined skull bones. Our study enabled to identify three distinguished features for this species and confirmed the validity of the species $O$. acuminatus.
\end{abstract}

\section{RÉSUMÉ}

Révision de l'anatomie crânienne d'Ophisaurus acuminatus Jörg, 1965 (Anguimorpha, Anguidae) de la fin du Miocène en Allemagne.

Le lézard anguiné Ophisaurus acuminatus Jörg, 1965 est connu par un seul spécimen du Miocène supérieur (MN 9) de Höwenegg/Hegau en Allemagne, comprenant des os crâniens et des ostéodermes. Depuis sa description, plusieurs autres espèces appartenant au genre Ophisaurus Daudin, 1803 ont été décrites dans divers gisements du Miocène européen. La diagnose de ces espèces est établie principalement sur des caractères du pariétal et dans une moindre mesure du frontal. Si la plupart des os d'O. acuminatus sont bien conservés, le pariétal manque. Une connaissance plus complète de l'anatomie de cette espèce d'anguiné est nécessaire pour établir ses relations avec les autres membres du genre Ophisaurus. Nous procédons à une nouvelle étude du spécimen type avec l'utilisation d'une technique moderne, la tomographie à rayons $\mathrm{X}$ à haute résolution. Cette méthode nous a permis: 1) de découvrir de nouveaux aspects de l'anatomie des os déjà étudiés; 2) de révéler la morphologie des os complétement recouverts par le sédiment; 3) d'identifier des os du crâne restés sans détermination jusqu'ici. Cette étude nous permet d'ajouter trois nouveaux caractères diagnostiques confirmant la validité de l'espèce $O$. acuminatus. 


\section{INTRODUCTION}

Although the fossil record of Anguinae is quite abundant in the Miocene of Europe, it consists mostly of disarticulated specimens. The complete or at least partially articulated skeletons of anguines are extremely rare. One partially articulated postcranial skeleton of Ophisaurus sp. was described from the middle Miocene of Slovakia (Klembara 1986; Čerňanský \& Klembara 2017) and one partially articulated skeleton of a small specimen of Ophisaurus holeci Klembara, 2015 was recently described from the middle Miocene of Germany (Čerňanský \& Klembara 2017). Thus, in most of the fossil finds, it is very difficult to associate the individual cranial and postcranial elements which would belong to one species.

The holotype of Ophisaurus acuminatus Jörg, 1965 first described by Jörg (1965) from the late Miocene of Germany belongs to these extremely rare cases where the bones are at least partially articulated or lie very close one to another and may be determined as belonging to one species with certainty. This specimen (SMNK-PAL.8561) consists of most skull bones (four of them are paired), both lower jaws and several osteoderms. Unfortunately, the parietal is not preserved. The taxonomy of the Cenozoic species of Ophisaurus Daudin, 1803 is based mostly on the morphology of the parietal bones (Klembara \& Rummel 2018). Nevertheless, the number and quality of preservation of all the skeletal elements of $O$. acuminatus and the restudy of these elements using new methods offer a further source of data for our understanding of the anatomical knowledge of the Cenozoic Ophisaurus.

The aims of this paper are: 1) using a high-resolution X-ray microcomputed tomography to segment all skeletal elements of SMNK-PAL.8561 of O. acuminatus; 2) to discover potentially new bones embedded in the sediment and not visible from the outside; and 3) on the basis of the re-study of the original anatomical data and the obtained new anatomical data to evaluate the taxonomic validity of $O$. acuminatus.

\section{GEOLOGICAL SETTING}

The Höwenegg fossil site (northern Hegau district, Southwest Germany) (or Hewenegg/Hegau of Jörg, 1965) was discovered in the 1930s. The locality represents a basaltic maar belonging to the Hegau volcanic complex, which extends from Immendingen to the vicinity of Singen (Südbaden) (Jörg et al. 1955). The locality is located about $2.5 \mathrm{~km}$ south of the village Immendingen. On the basis of radiometric analyses, the age is dated to $10.3 \pm 0.19 \mathrm{Ma}$ (Swisher 1996; the lower part of the Vallesian continental stage), which correspondents to the MN 9 of the European Neogene Mammal biochronological system (Steininger 1999). This was also confirmed by Woodburne et al. (1996) and Munk et al. (2007). The volcano-detritic sediments, forming fossiliferous layers, form a sequence of white or grey marl-layers alternating with reddishbrown layers that are interpreted to be tuffaceous mudflows (Jörg 1954; Munk et al. 2007). The fauna was deposited in a lacustrine environment (Böhme \& Ilg 2003; Giersch et al.
2010). According to Bernor et al. (1997), the lake sediments have been deposited within a quite short geochronological interval. The locality yielded diverse vertebrate fauna of the late Miocene, among them fish (e.g., Gaudant 2015) and mammals (e.g., hipparions and beavers, Tobien 1938; Bernor et al. 1997; Giersch et al. 2010). Reptiles are represented by turtles (Schleich 1986) and one anguine taxon - O. acuminatus (Jörg 1965).

\section{MATERIAL AND METHODS}

\begin{tabular}{|c|c|}
\hline \multicolumn{2}{|c|}{ INSTITUTIONAL ABBREVIATIONS } \\
\hline AMNH & American Museum of Natural History, New York; \\
\hline CM & Carnegie Museum of Natural History, Pittsburg; \\
\hline $\mathrm{DE}$ & $\begin{array}{l}\text { Department of Ecology, Faculty of Natural Sciences, } \\
\text { Comenius University, Bratislava; }\end{array}$ \\
\hline SMNK & State Museum for Natural History, Karlsruhe; \\
\hline & University of Florida, Gainesville; \\
\hline ZFMK & $\begin{array}{l}\text { Zoologisches Forschungsmuseum Alexander Koenig, } \\
\text { Bonn. }\end{array}$ \\
\hline
\end{tabular}

DESCRIPTION AND PRESERVATION

The holotype SMNK-PAL.8561 of O. acuminatus consists of most of the bones of the skull and both lower jaws (Figs 1;2A). With these skull elements, several osteoderms are also associated. The bones of the skull are slightly displaced and moreor-less embedded in the sediment. It may be estimated that the skull was about $43 \mathrm{~mm}$ long; the length of the left lower jaw is about $41 \mathrm{~mm}$.

The anatomical terminology of the individual bony structures is here used as that for Pseudopus apodus (Pallas, 1775) (Klembara et al. 2014, 2017).

SPECIMENS OF ANGUINES USED FOR COMPARISONS

Ophisaurus ventralis (Linnaeus, 1766): DE 34, 35, 38, 99a, 100a; AMNH 73057; UF 52539; CM 1411; ZFMK 27411, 95414;

O. attenuatus Cope, 1880: DE 32, 33, 43, 44;

O. compressus Cope, 1900: DE 50; ZFMK 32194;

O. mimicus Palmer, 1987: DE 49;

O. (Hyalosaurus) koellikeri Günther, 1873: DE 30, 41; ZFMK 13118, 13119;

O. (Dopasia) harti Boulenger, 1899: DE 36, 37, 56, 57, 86; AMNH 34956; ZFMK 9472;

O. (Dopasia) gracilis Gray, 1845: DE 42;

Anguis fragilis Linnaeus, 1758: DE 14-21, 24, 25, 45-48, 102a, 103a;

Pseudopus apodus (Pallas, 1775): DE 4, 6, 8, 10, 52, 53, 58.

X-RAY MICROTOMOGRAPHY, THREE-DIMENSIONAL

VISUALIZATION AND PHOTOGRAPHY

The specimen was scanned using the micro-computed tomography (CT) facility at the Museum für Naturkunde Berlin, Germany, using a Phoenix GE Nanotom with the following settings: VxSize $=0.02415382$; Current $=170$; Voltage $=90 ;$ Inttime $=1000 ;$ Average $=3$; Steps $=1600 ;$ Steps360 $=1440$. The images were recorded over $360^{\circ}$. The 


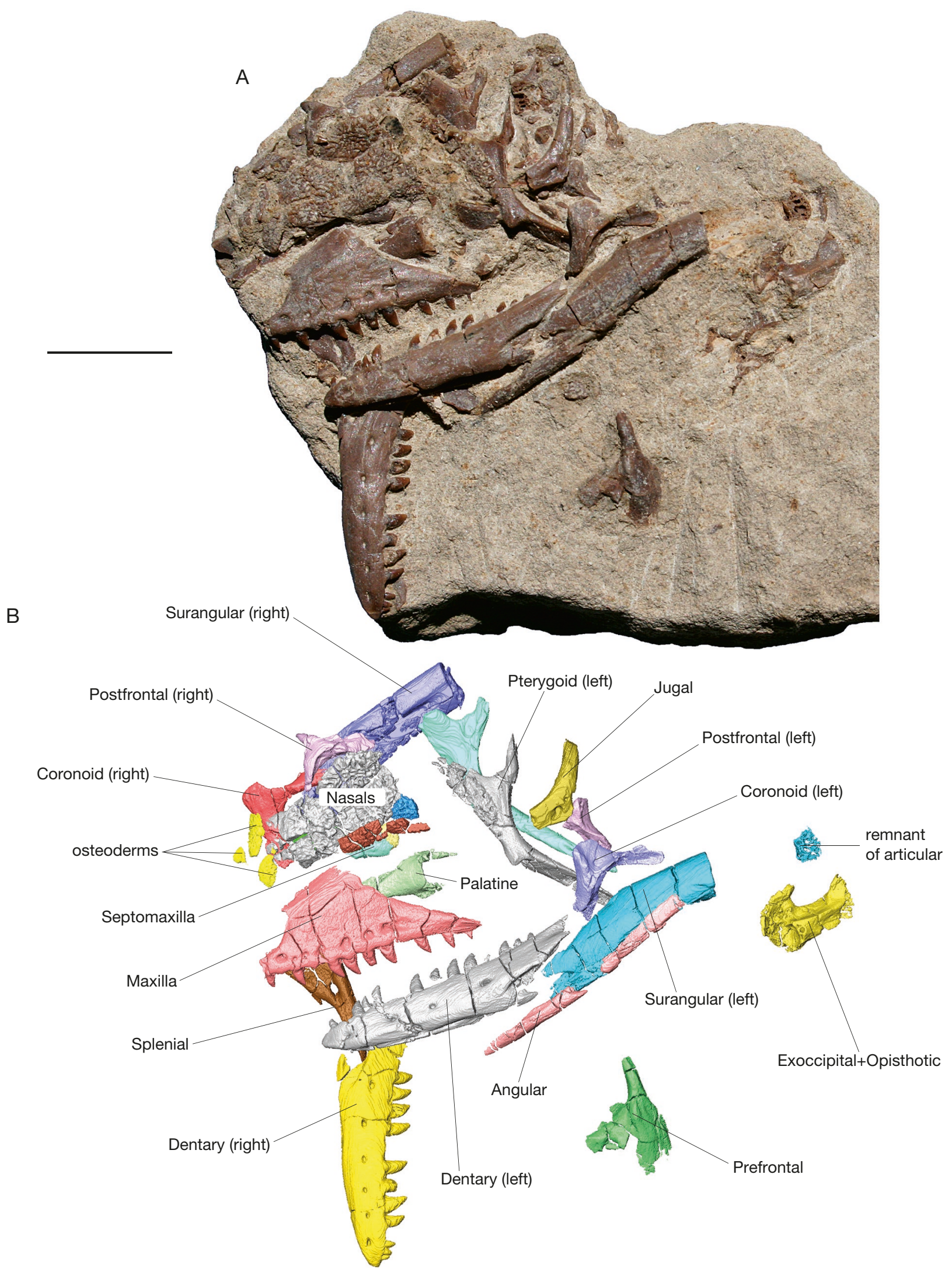

FIG. 1. - Ophisaurus acuminatus Jörg, 1965, SMNK-PAL.8561: A, holotype of slightly disarticulated skull; B, virtual 3D models of individual bones of the same specimen. Scale bar: $10 \mathrm{~mm}$. 
CT data-set was analyzed using AVIZO 8.1 on a high-end computer workstation. The photographs of the fossil were taken using a Nikon D90 camera. The specimen was coated with ammonium chloride prior to photography (Fig. 11C). The photographs of individual bones were taken using a Leica M205 C binocular microscope with an axially mounted DFC 290 HD camera; software: LAS (Leica Application Suite) 4.1 .0 (build 1264).

\section{SYSTEMATIC PALAEONTOLOGY}

\author{
Order SQUAMATA Oppel, 1811 \\ Infraorder ANGUIMORPHA Fürbringer, 1900 \\ Family ANGUidAE Gray, 1825 \\ Subfamily ANGUINAE Gray, 1825 \\ Genus Ophisaurus Daudin, 1803
}

\section{Ophisaurus acuminatus Jörg, 1965}

(Figs 1-14)

Ophisaurus acuminatus Jörg, 1965: 21.

HOLOTYPE. - SMNK-PAL.8561, almost complete and partially disarticulated skull and lower jaws (Figs 1;2A).

REFERRED SPECIMENS. - SMNK-PAL.8690, left isolated prefrontal (Fig. 5D, E); SMNK-PAL.8610, ten osteoderms (Fig. 14).

LOCALITY AND AGE. — Höwenegg/Hegau (near the city Öhningen), Germany. Late Miocene (MN 9).

DifFERENTIAL DIAGNOSIS. - On the basis of the present study, the species $O$. acuminatus differs from all fossil and Recent species of Ophisaurus by the following distinguished features: 1) distinct ornamentation of nasal and frontal bones (relatively broader and massively developed ridges and tubercles); 2) mediolaterally almost straight posterior margins of posterior ornamented shields of nasals and 3) on the medial surface of the lower jaw, anterior margin of anterior mylohyoid foramen lies only slightly posterior to the level of posterior margin of anterior inferior alveolar foramen.

\section{DESCRIPTION}

Jörg (1965) described the following bones of skull and lower jaw of O. acuminatus: prefrontal, maxilla, jugal, pterygoid, dentary, angular, coronoid, surangular, articular and osteoderms. Below, the correctness of the descriptions of these bones is confirmed or modified in the light of a better accessibility to the anatomical data using high-resolution X-ray microcomputed tomography. All other elements described below are new.

\section{Skull}

Septomaxilla. Most of the body of the right septomaxilla is preserved (Figs 1B; 2). Its dorsal wall is smooth. The root portions of the posterolateral and posteromedial processes are preserved. The margin of the septomaxillary process of vomer articulation is rounded. The roof of Jacobson's chamber is smooth and is surrounded by a distinct marginal crest. The lateral lamina is well-developed and extends ventrolaterally.
Nasal. The nasal is an elongated, paired bone (Figs 1; 3; 4A-C). The median suture is straight. The premaxillary process narrows anteromedially. Only the posterior portions of the anterolateral processes are preserved. Their surfaces are smooth. Both processes form a rounded posteromedial margin of the exonarial fenestra. The dorsal surface of nasals is covered with two pairs of ornamented shields. The anterior ornamented shields are slightly smaller than the posterior shields and the right anterior ornamented shield is larger than the left one. The ornamentation consists of distinctly developed ridges and broad intervening grooves. On all four shields the ossification centres are well recognizable. They lie in about the centres of the shields. The right anterior shield is of about semilunar shape; the left anterior shield is of about oval shape. The posterior portion of the right anterior shield extends medially, slightly posterior to the left anterior shield. The posteromedian portions of both anterior shields have a form of a wedge; the wedge fits between the anterior portions of the posterior shields. The anteromedial margin of the right posterior shield is perfectly preserved. It is straight and runs in anterolateral-posteromedial direction. Its anterolateral margin has an anteromedial-posterolateral course and its posterolateral margin runs in anterolateral-posteromedial direction. The right and left posterior ornamented shields meet in more-or-less straight median suture. The posterior margins of the posterior ornamented shields are lateromedially almost straight; this is in contrast to all other anguines (Fig. 4, see below).

The ventral surface of the nasals is finely coarse (Fig. 4B). The lateral margin of the anterior half of the nasal is distinctly developed and flexed ventrolaterally, thus both nasals form a shallow and wide trough anteriorly.

Remarks. The only fossil species of Ophisaurus in which the nasal is preserved is O. holeci (Čerňanský \& Klembara 2017). This specimen is much smaller than that of $O$. acuminatus. The ornamentation of its nasal differs substantially from that of $O$. acuminatus: it consists of distinct pits of different size and very short grooves. Such ornamentation as present in $O$. holeci is not present in any other species of Ophisaurus.

\section{Prefrontal}

The right and left prefrontals are preserved, however, in both bones most of the wall of the olfactory chamber is damaged (Fig. 5A-E). The prefrontal is of about triangular shape and posteriorly extends into a stout frontal process. The frontal process is well preserved and is almost as long as the rest of the preserved portion of the prefrontal. Along the medial margin of the frontal process, a distinct frontal articulation is present. Only a small portion of the nasal articulation is present at the left prefrontal (Fig. 5E). The ventrolateral portion of both prefrontals is broken on several places, but the outline of the lacrimal foramen is well recognizable on the right prefrontal (Fig. 5A, B). The anteriormost portion of the olfactory chamber is deep and well demarcated by a sharp rounded ridge (Fig. 5C). 


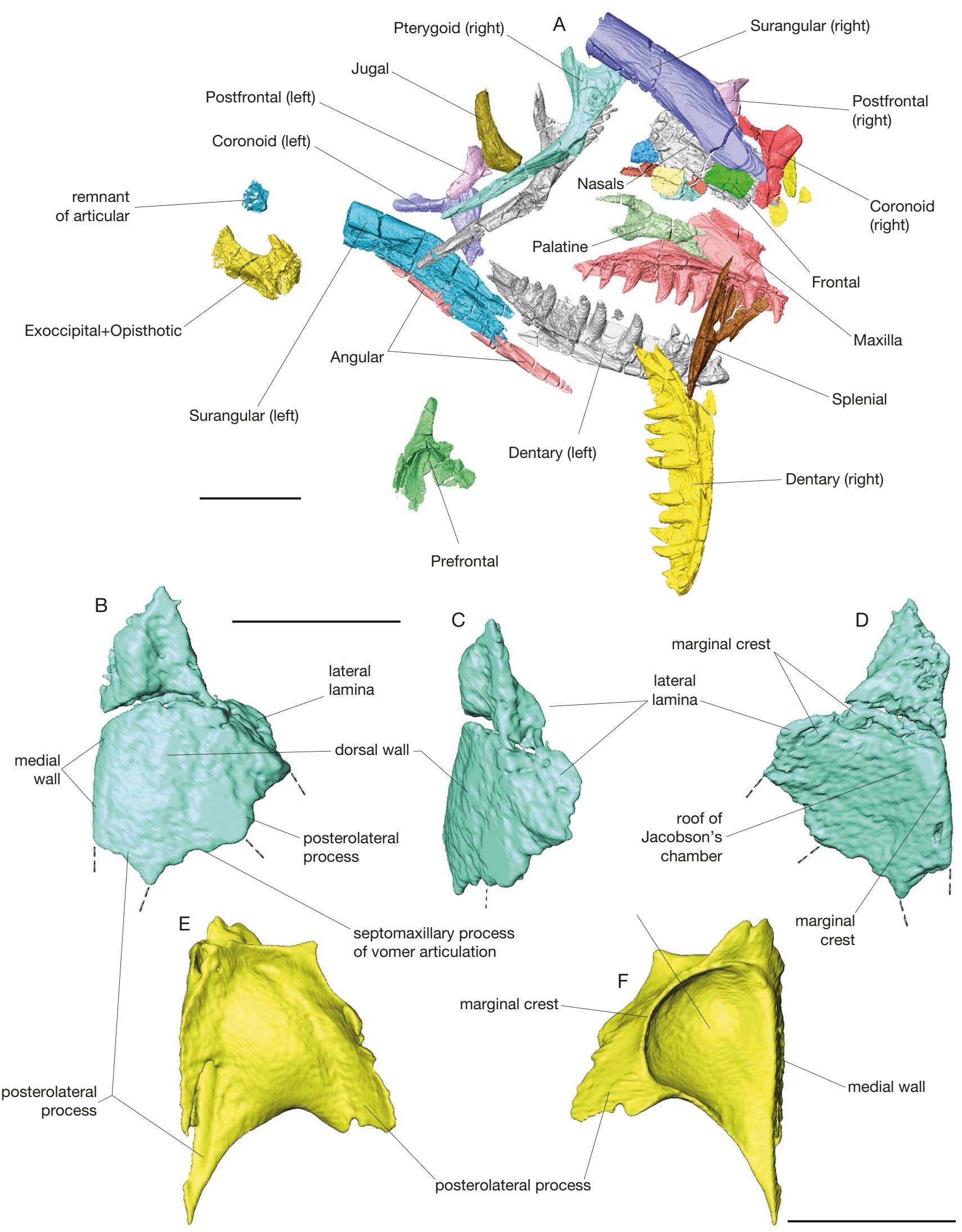

FIG. 2. - A-D, Ophisaurus acuminatus Jörg, 1965, SMNK-PAL.8561: A, virtual 3D models of individual bones of holotype skull in internal view; B-D, right septomaxilla in dorsal (B), laterodorsal (C) and ventral (D) views; $\mathbf{E}, \mathbf{F}$, right septomaxilla of Ophisaurus attenuatus in dorsal (E) and ventral (F) views. Scale bars: $\mathbf{A}$ $10 \mathrm{~mm}$; B-F, $2 \mathrm{~mm}$. 

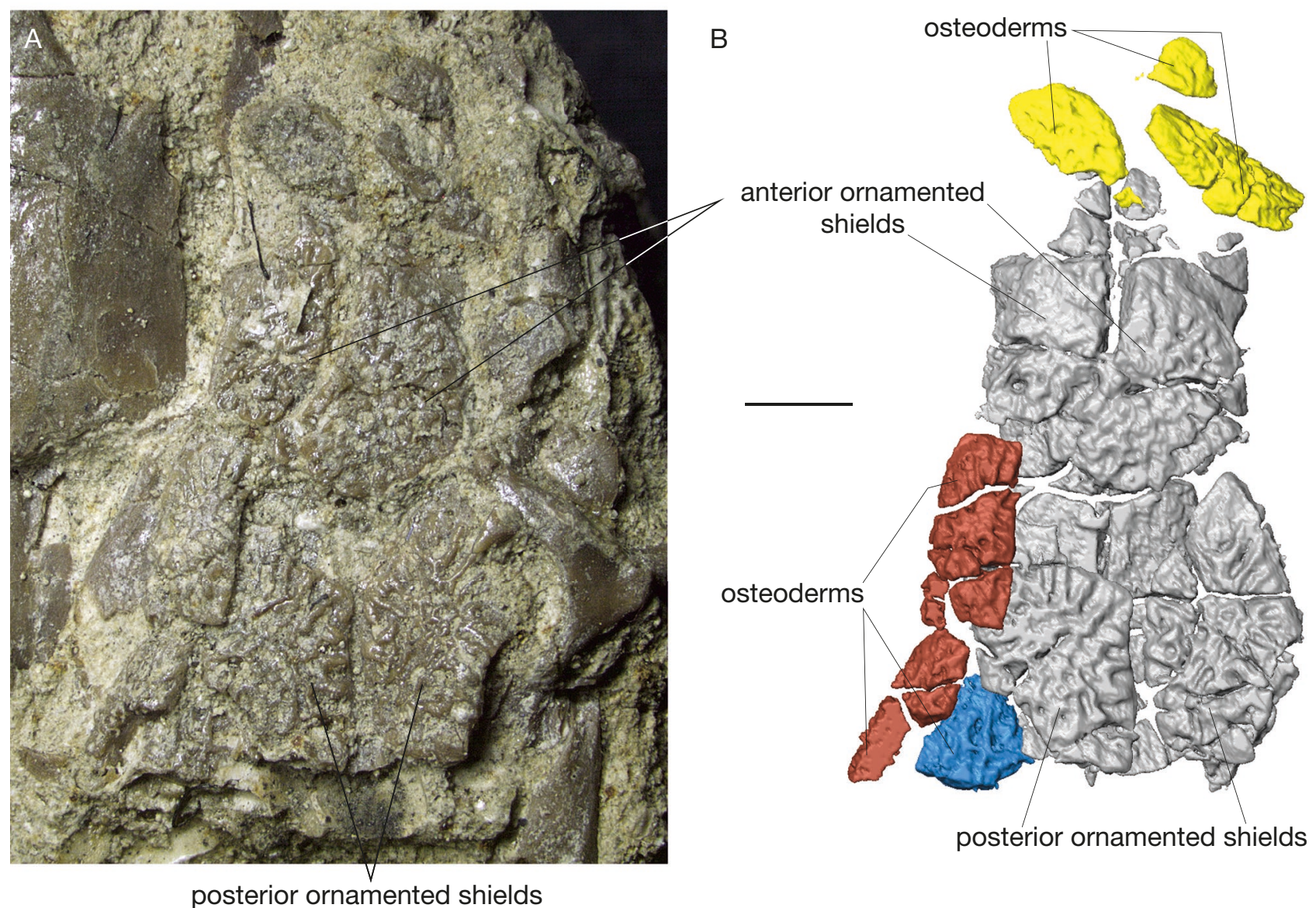

FIG. 3. - Ophisaurus acuminatus Jörg, 1965, SMNK-PAL.8561: A, photograph of nasals in dorsal view; B, virtual 3D models of nasals and surrounding osteoderms in dorsal view. Scale bar : $2 \mathrm{~mm}$.

\section{Frontal}

The posterior portion of the left frontal is preserved (Fig. 5F, G). The dorsal ornamented surface is distinct. The ornamentation reaches the orbital margin of the preserved portion of the frontal. The lateral frontal sulcus is slightly longer than the medial frontal sulcus. The lateral frontal sulcus runs in anterolateral-posteromedial direction. The medial frontal sulcus is shorter and has a mediolateral course. The place of junction of both sulci is overlapped by ornamentation. The territory of the dorsal surface of the frontal, posterior to both sulci, is also distinctly ornamented, so the junction of the frontoparietal and interfrontal shields is obscured. The posterolateral process is distinct. Most of its dorsal surface is covered by the frontoparietal shield. Only posteriormost surface of the posterolateral process is smooth (Fig. 5F). Most of the ventral surface of the frontal is smooth. A low ridge runs close to the lateral margin of the bone and fades out at the posterolateral process of the frontal. This ridge represents the posteriormost portion of the frontal cranial crest (Fig. 5G).

Remarks. Although the potential junction of the lateral and medial frontal sulci is partially obscured, it is possible to estimate that the lateral sulcus is longer that the medial sulcus. Such condition is present in the frontal bones in several modern species of Ophisaurus, as well as those found in the Cenozoic of Europe and North Africa (e.g., Delfino et al. 2011; Blain etal. 2013; Klembara 2015).

\section{Postfrontal}

The right complete postfrontal and almost complete left postfrontal are preserved (Fig. 6). The postfrontal is a triradiate bone consisting of the frontal, jugal and long parietal processes. The jugal process is slightly shorter than the frontal process. The rounded orbital margin is the deepest at the level of the long ventrolateral margin of the parietal process. The anteriorly tapering frontal process bears a deep groove for the articulation with the frontal. The groove gradually continues posteriorly and forms the articulating surface for the parietal. Short jugal and long postorbital articulating surfaces are better developed on the right postfrontal. The parietal process is of rectangular shape and bears a foramen at its posterior end (present only on the left postfrontal). The left postfrontal shows a dorsoventrally broad articular surface for the anterolateral process of the parietal.

\section{Maxilla}

The left maxilla is almost completely preserved (Figs $1 ; 2 \mathrm{~A}$; 7A-D). Its nasal process is prominent and of trapezoidal shape. The dorsal portion of the nasal process is slightly curved medially. The external surface of the maxilla is rather smooth; a weak rugosity is present only in its anterior portion. The surface ventral to the nasal process 


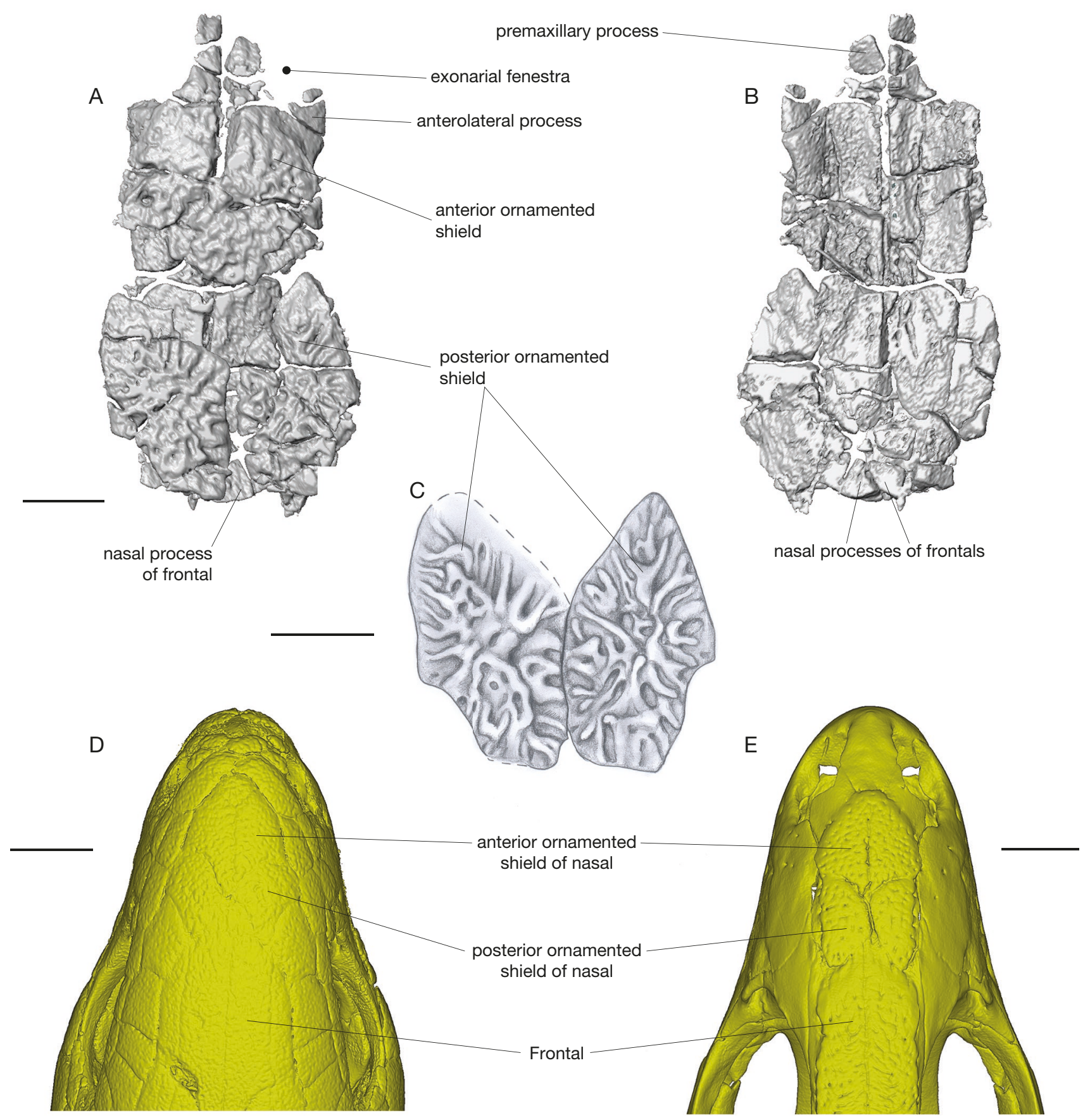

FIG. 4. - A-C, Ophisaurus acuminatus Jörg, 1965, SMNK-PAL.8561: A, B, virtual 3D models of nasals in dorsal (A) and ventral (B) views; C, reconstruction of posterior ornamented shields in dorsal view; D, E, virtual 3D models of anterior portions of skulls of Ophisaurus ventralis (Linnaeus, 1766) (ZFMK 95414) (D) and Ophisaurus attenuatus Baird, 1880 (DE 43) (E) in dorsal views. Scale bars: A-C, 2 mm; D, 3 mm; E, 2.5 mm.

is pierced by seven labial foramina of various size. They are arranged in a single line. A shallow groove is associated with the posteriormost foramen which is located at the level of the 7 th tooth position (counted from posterior). The posterior portion of the maxilla gradually dorsoventrally narrows into a pointed process. Its dorsal margin, gradually passing into the posterior margin of the nasal process, is almost straight. The anterior margin of the maxilla is concave and forms the posterodorsal margin of the exonarial fenestra.
Unfortunately, both rami of the premaxillary process are broken. In medial aspect, the maxilla bears a slightly dorsally convex supradental shelf (sensu Rage \& Augé 2010). It bears 14 tooth positions (nine teeth are preserved). The palatine articulation lies at the level of $5^{\text {th }}$ and $6^{\text {th }}$ tooth positions (counted from posterior). Immediately anterior to it, a large superior alveolar foramen is located. On the medial surface of the nasal process, a distinct rugosity marks the prefrontal articulation. 


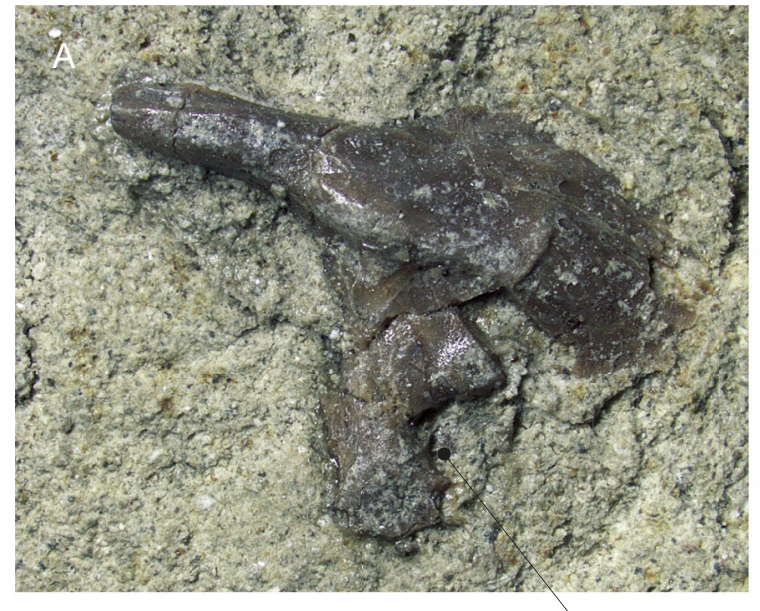

D

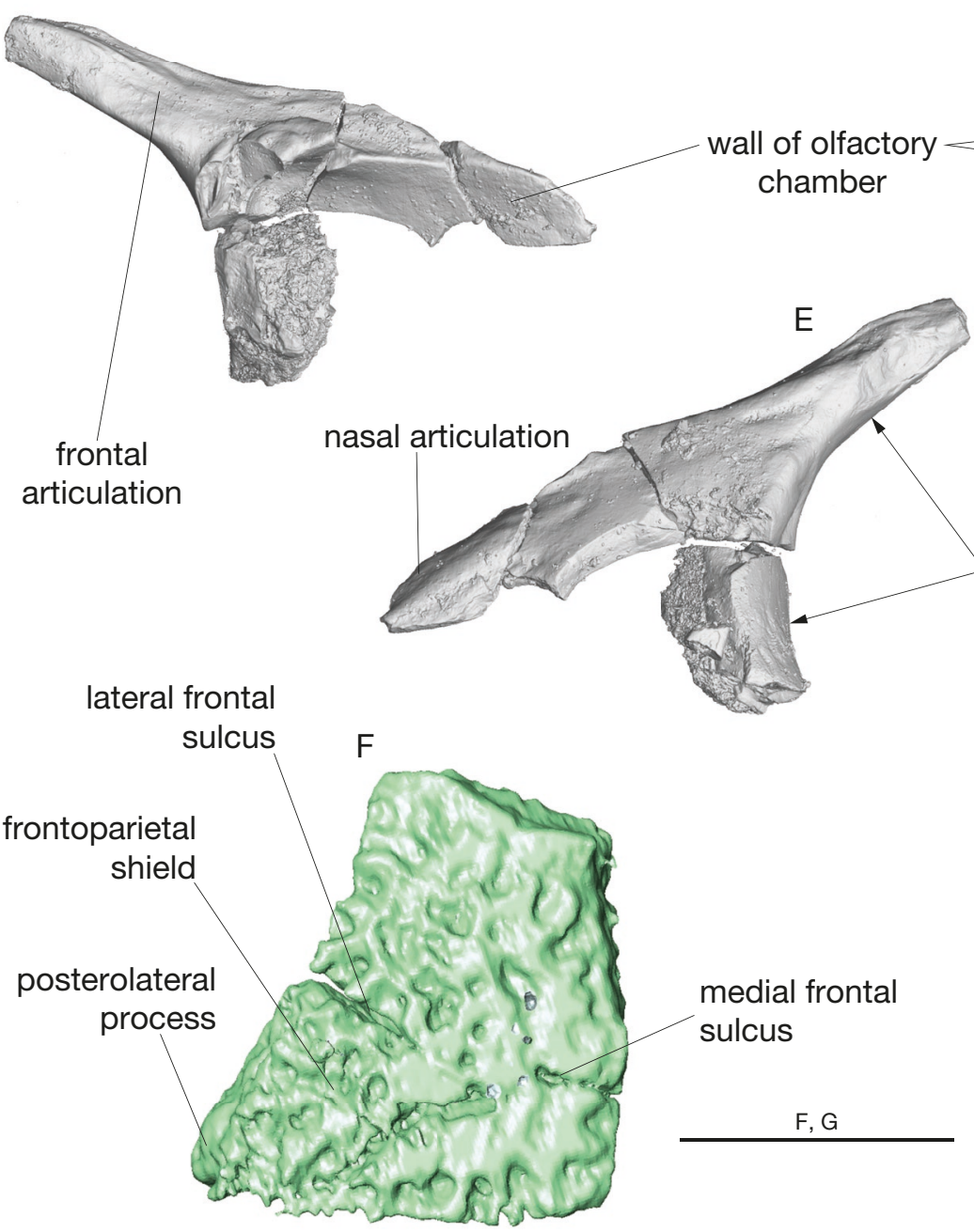

B

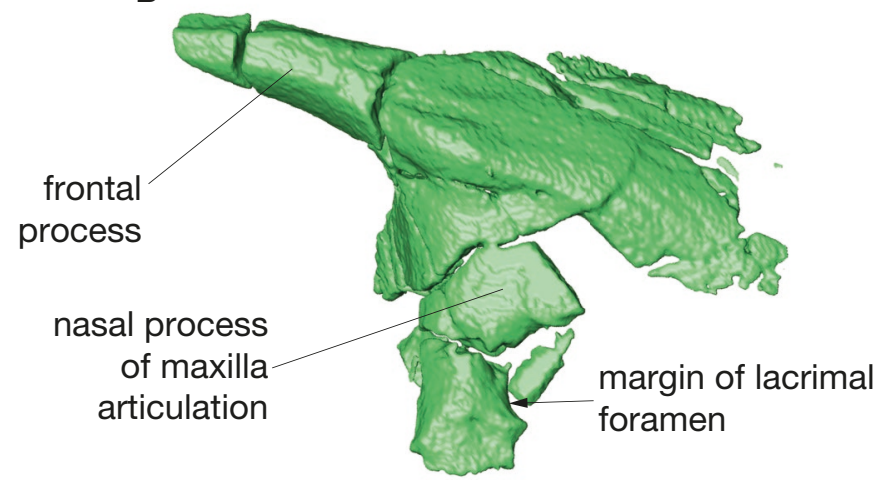

of maxilla

articulation foramen

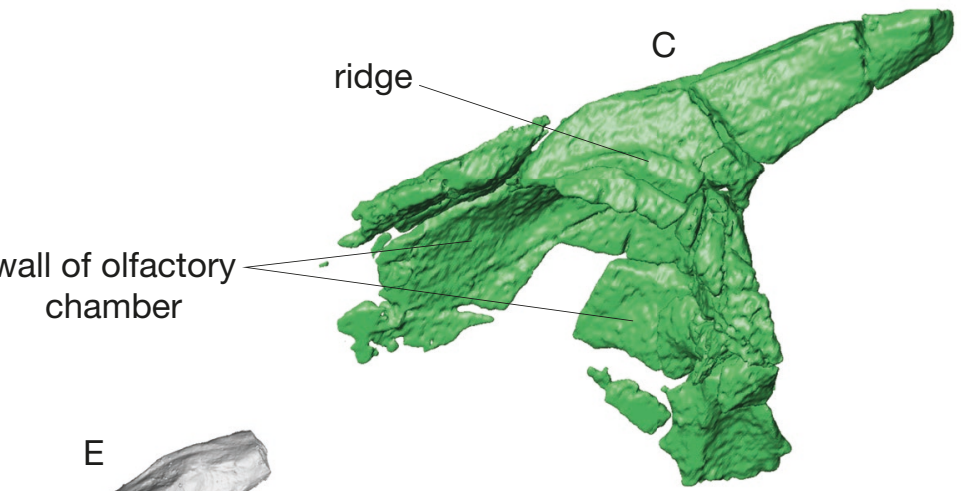

FIG. 5. - Ophisaurus acuminatus Jörg, 1965: A-C, SMNK-PAL.8561, photograph (A) and virtual 3D models of right prefrontal in lateral (A, B) and medial (C) views; D, E, SMNK-PAL.8690, virtual 3D models of left prefrontal in lateral (D) and medial (E) views; $\mathbf{F}$, G, posterior portion of left frontal bone in dorsal (F) and ventral (G) views. Scale bars: $2 \mathrm{~mm}$.

Jugal

Most of the left jugal is preserved (Figs 1; 2A; 7E, F). In the central portion, the external surface of the jugal is pierced by two foramina - a large suborbital foramen and an additional smaller foramen located slightly posterodor- sally to it. The posterior portion of the suborbital process is robustly constructed. The internal surface of the jugal bears a medial ridge. The base of the posteroventral process of the jugal is well preserved and indicates the presence of a distinct process. 


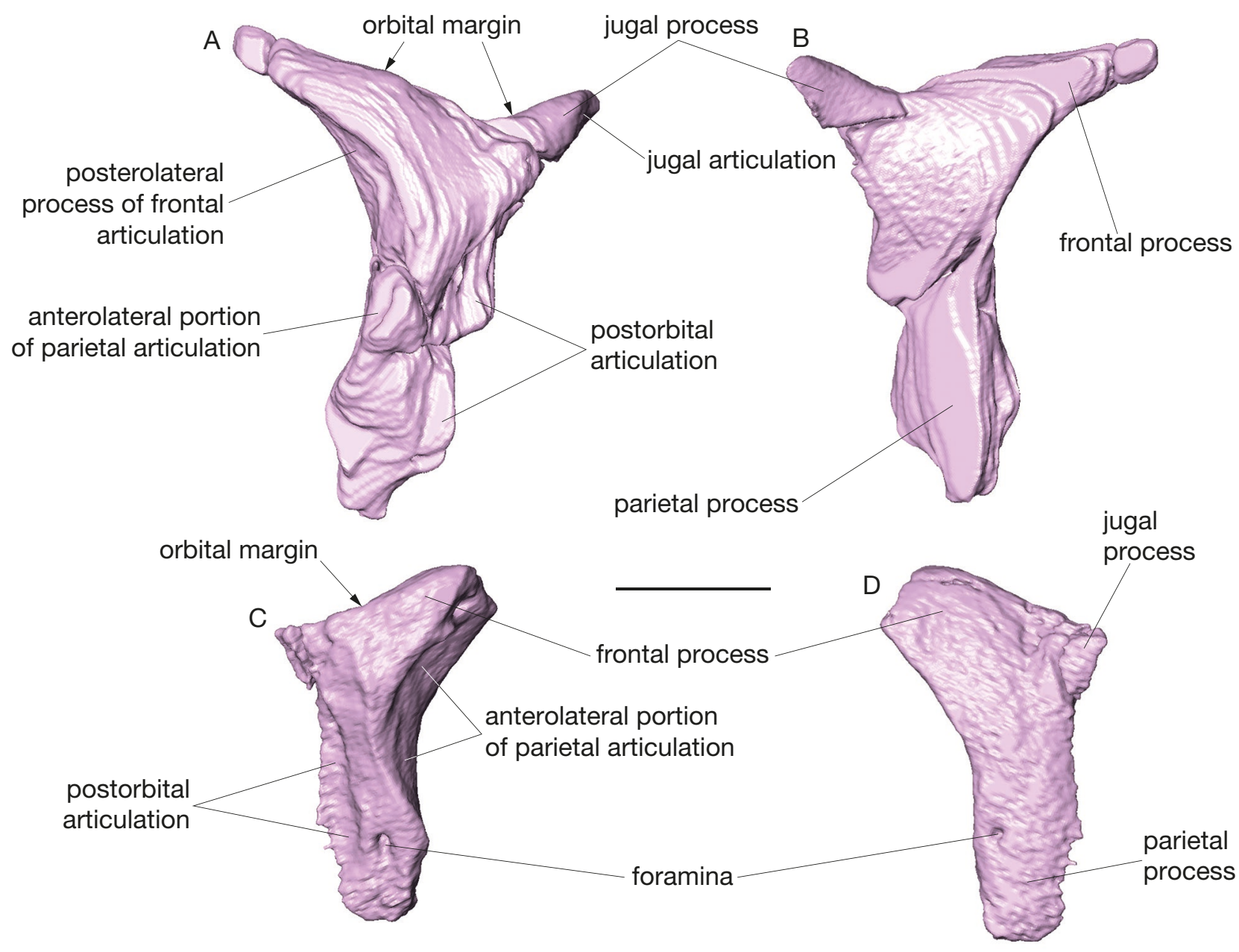

FIG. 6. - Ophisaurus acuminatus Jörg, 1965, SMNK-PAL.8561: A, B, right postfrontal in dorsolateral (A) and ventrolateral (B) views; C, D, left postfrontal in dorsolateral (C) and ventrolateral (D) views. Scale bar: $2 \mathrm{~mm}$.

\section{Palatine}

Almost completely preserved right palatine is present (Fig. 8A, B). It is an anteroposteriorly elongated and flat bone. The proximal portion of the maxillary process is preserved and contains the infraorbital foramen. The vomerine process is straight, slender, much longer than the maxillary process and tapers anteriorly. The pterygoid process extends posteriorly, and the pterygoid articulation is distinct. On the ventral surface of the palatine the lateral margin of the pterygoid articulation forms a crest medially limiting the rows of teeth positions. The teeth are not preserved, but a short anteroposteriorly running series of pits indicating their positions is clearly recognizable (Fig. 8A). Most of the dorsal surface is smooth. On the dorsal surface the palatine groove is distinct and runs in anteromedial-posterolateral direction.

\section{Pterygoid}

Both pterygoids are preserved (Figs 1; 2; 9). The pterygoid is a triradiate bone. The anteriormost portion of the palatine process is missing. However, most of the denticle field is well preserved. The pterygoid sulcus is deep and broad and gradually narrows posteriorly (Fig. 9B, E). The anterolaterally extending transverse process bears a well-developed ectoptery- goid articulation. The quadrate process is long and straight and bears a long pterygoid groove at its dorsal surface. The groove is anteriorly confluent with the epipterygoid fossa. The basipterygoid articulation is shallow. The obtuse process is distinct and rounded. The epipterygoid fossa lies at the level of the posterior portion of the obtuse process. The body of the pterygoid is narrowest in a short distance anteriorly to the obtuse process.

Remarks. The pterygoids of the fossil Ophisaurus are known from several Miocene and Pliocene localities in Europe (e.g., Klembara 1981, 2015; Delfino et al. 2011). The general morphology of these fossil pterygoids is very similar to that described here for $O$. acuminatus. The distinctive feature of all these fossil species of Ophisaurus is a relatively large denticulated field mostly composed of more or less distinct anteroposteriorly running rows of denticles; the most robust denticles lie in the most lateral row. The pterygoids of early Miocene Pseudopus ahnikoviensis Klembara, 2012 are similarly built as those of contemporaneous specimens of Ophisaurus, however, the pterygoid of $P$. ahnikoviensis bears a distinct feature - the oblong crest lying on the ventral surface of the transverse process of the pterygoid (Klembara 2012). The 

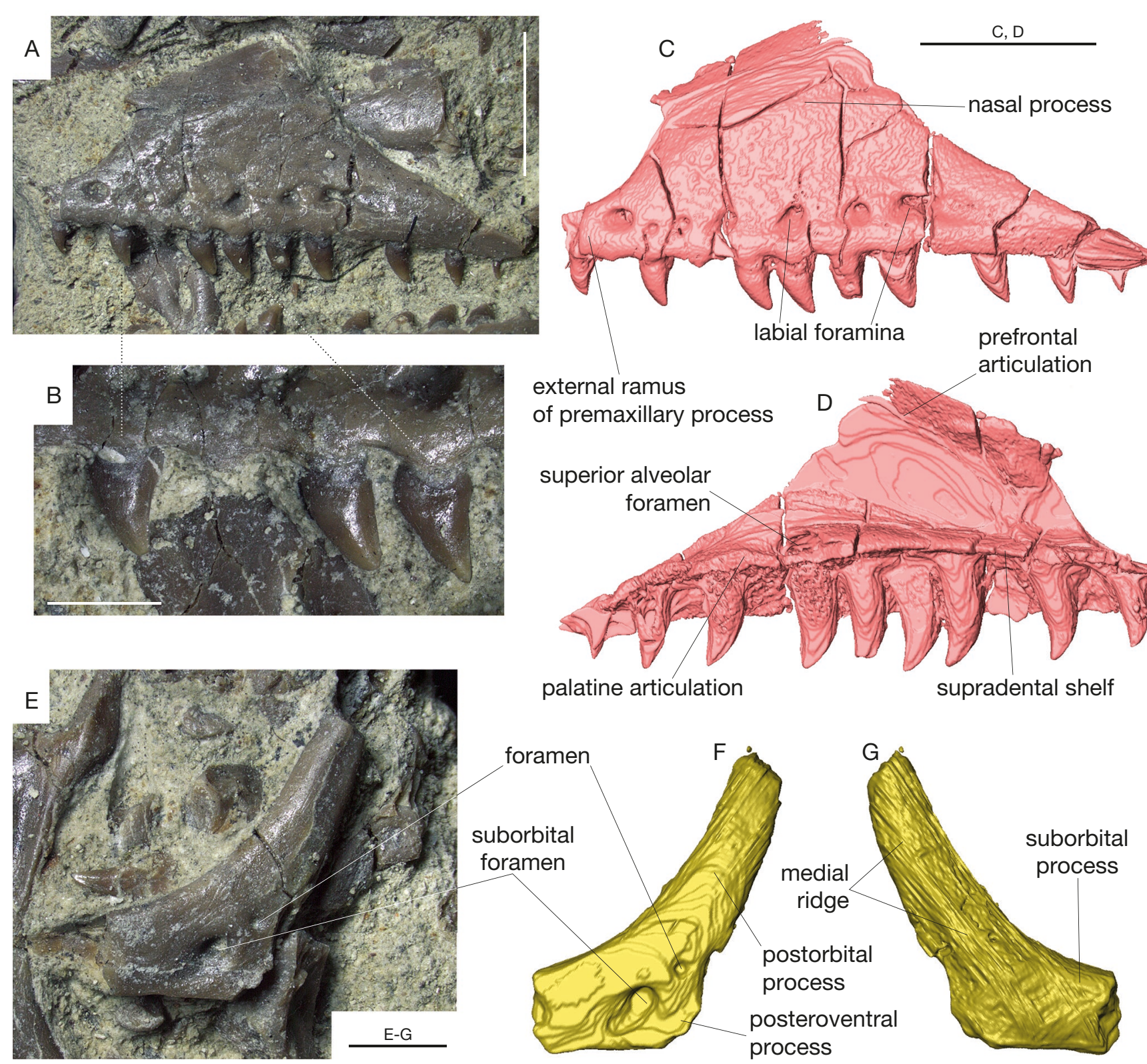

FIG. 7. - Ophisaurus acuminatus Jörg, 1965, SMNK-PAL.8561: A, B, photographs of left maxilla (A) and detail of teeth (B) in lateral view; C, D, virtual 3D model of left maxilla in lateral (C) and medial (D) views; $\mathbf{E}-\mathbf{G}$, photograph (E) and virtual 3D models (F, G) of left jugal in lateral (E, F) and medial (G) views. Scale bars: A, B, $1 \mathrm{~mm}$; C, D, $5 \mathrm{~mm}$; E-G, $2 \mathrm{~mm}$. presence of the oblong crest is a shared feature by three species of Pseudopus: P. ahnikoviensis, P. Laurillardi (Lartet, 1851) and P. pannonicus (Kormos, 1911) (Klembara et al. 2010).

\section{Exoccipital and opisthotic}

A substantial portion of the right exoccipital and opisthotic is preserved and both bones are fused together (Figs 1; 2; 10). The paroccipital process is fan-like at its distal end. On the posterior surface of the paroccipital process, a distinct and sharp ridge passes posterolaterally. The ridge gradually diminishes posteriorly and is confluent with the articular surface of the paroccipital process. Dorsally to the proximal portion of the ridge, the opening for the lateral semicircular canal is present (Fig. 10A-C). Immediately anterior to the

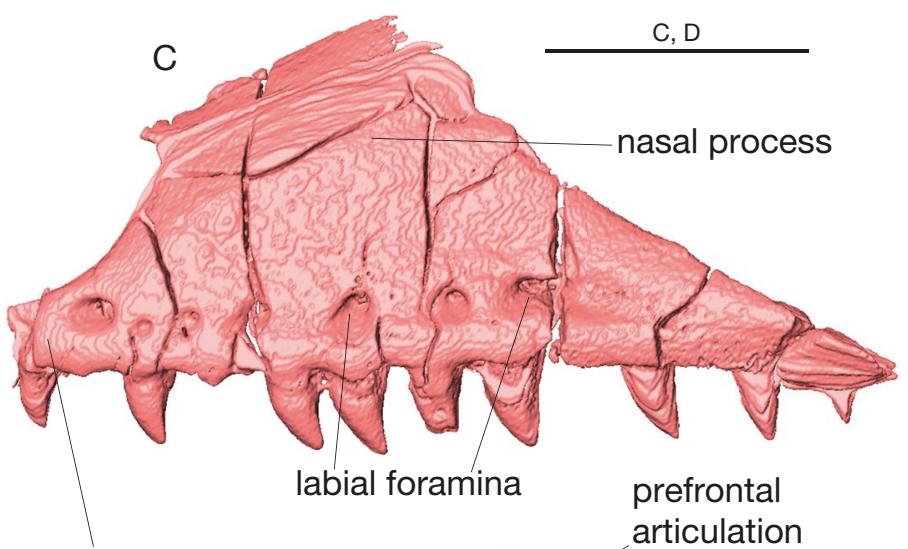

external ramus of premaxillary process

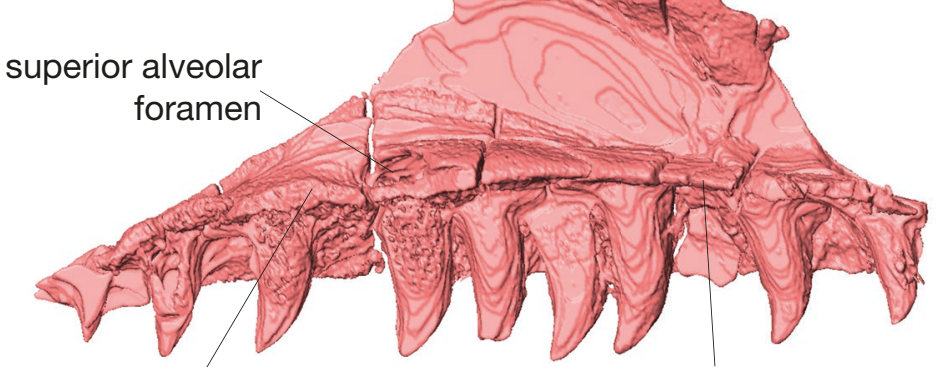

alatine articulation opening of the semicircular canal is a rounded margin limiting a deep excavation; the excavation represents a posterodorsal portion of the vestibule (Fig. 10B, C). Immediately ventral to it, a rounded depression marks the wall of the cochlear recess (Fig. 10B). The proximal portion of the fused exoccipital-opisthotic is on several places damaged, but the vagus foramen marking the original exoccipital-opisthotic suture is present (Fig. 10C, D).

\section{LOWER JAW (FIGS 1; 2A; 11-13)}

\section{Dentary}

Both dentaries are preserved (Figs 1; 2A; Fig. 11C, F, G; 12). The dentary is anteroposteriorly elongate and gradually narrows anteriorly. The smooth lateral surface of the bone is 


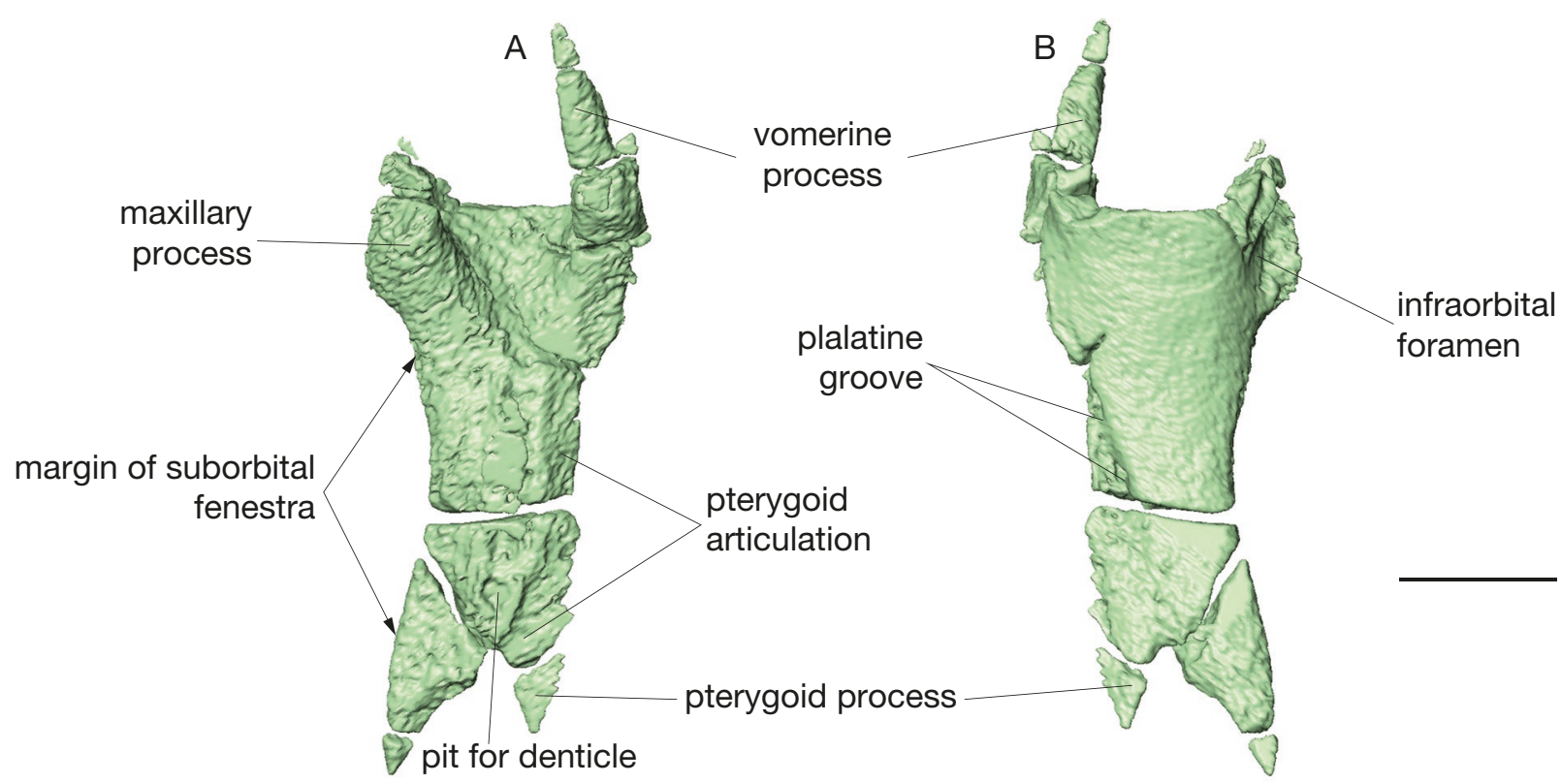

FIG. 8. - Ophisaurus acuminatus Jörg, 1965, SMNK-PAL.8561: A, B, virtual 3D models of right palatine in ventral (A) and dorsal (B) views. Scale bar: 2 mm.

pierced by six mental foramina (well preserved in the left dentary). A high dorsal crest supports fifteen tooth positions (eleven teeth are preserved in each dentary). The dental crest is concave and anteriorly passes into a small symphyseal facet. The crest is flexed ventrally along its entire length. It bears a splenial spine at the level between the fourth and fifth tooth positions (counted from posterior). The splenial spine forms an anteroventral margin of the anterior inferior alveolar foramen (Figs 11G; 12C). Posteriorly to it, the dental crest is curved dorsally, being thinner than its anteriorly located portion. Meckel's groove is narrow, opens ventrally rather than medially (Fig. 12D). The alveolar foramen is located at the level of the third tooth position (counted from posterior) (Fig. 11G). Posteroventrally to this foramen, the surangular spine is present; however, only its root portion is preserved in the left dentary (Fig. 11G). The intramandibular septum is better preserved on the right dentary and has about a vertical position (Fig. 12D). The posteroventral region of the dentary ends by a distinct angular process. It is of triangular shape. Its posterior termination reaches the level of the penultimate tooth position (Fig. 12). The posterodorsal portion of the dentary is elevated dorsally. The surangular and coronoid processes are pointed. The coronoid process reaches slightly more posteriorly than the surangular process. A shallow coronoid incisure is located between both processes (Fig. 12B-D).

\section{Splenial}

The right splenial is well preserved (Figs 1; 2A; 13C-E). Anteriorly it extends into a pointed process. Posteriorly it gradually dorsoventrally broadens. Posteroventrally, the splenial extends into a long, narrow and pointed process. The dorsally to it lying portion of the splenial is partially damaged, but the presence of two other processes is indicated. At the half of the anteroposterior length of the splenial, the anterodorsal margin is stepped forming a roughly triangular small process. The process is hooked anteriorly. This structure forms the posterior and ventral margins of the anterior inferior alveolar foramen. In the central portion of the bone, a large mylohyoid foramen is present. It lies only slightly posterior to the level of the posterior margin of the anterior inferior alveolar foramen.

\section{Angular}

The left angular is preserved; it is an elongate bone lying at the ventral wall of the lower jaw (Figs 1; 2A; 11C, F, G). The anterior portion of the angular contacts the posteroventral portion of the dentary. An anteroposteriorly elongated depression on the medial surface of the angular indicates the presence of the posterior mylohyoid foramen (Fig. 11G). The posterior portion of the angular supports the surangular partly ventrally and medially, and mostly laterally.

\section{Coronoid}

Both left and right coronoids are preserved (Figs 1; 2A; 11CG; 13A, B). The coronoid is a chevron shaped bone, with four processes: the dorsal, anterolateral, anteromedial and posterior processes. The dorsal process lies in the mid-length of the bone. It is of quadrangular shape. Although it is shorter than other two processes, its overall appearance is robust. The dorsal process is slightly inclined posteriorly. Its anterolateral portion bears a distinct ridge (or keel) for muscle attachment (Figs 11E; 13A). The medial side of the process is flat. The posterior process is longer than the anteromedial process. It is bent laterally to form a contact with the surangular. This articulation is bordered dorsally by a sharp muscular crest (Fig. 13A). The medial side of the posterior process bears a low ridge. This ridge forms the anterior border of the mandibular/adductor fossa (Fig. 11G). 


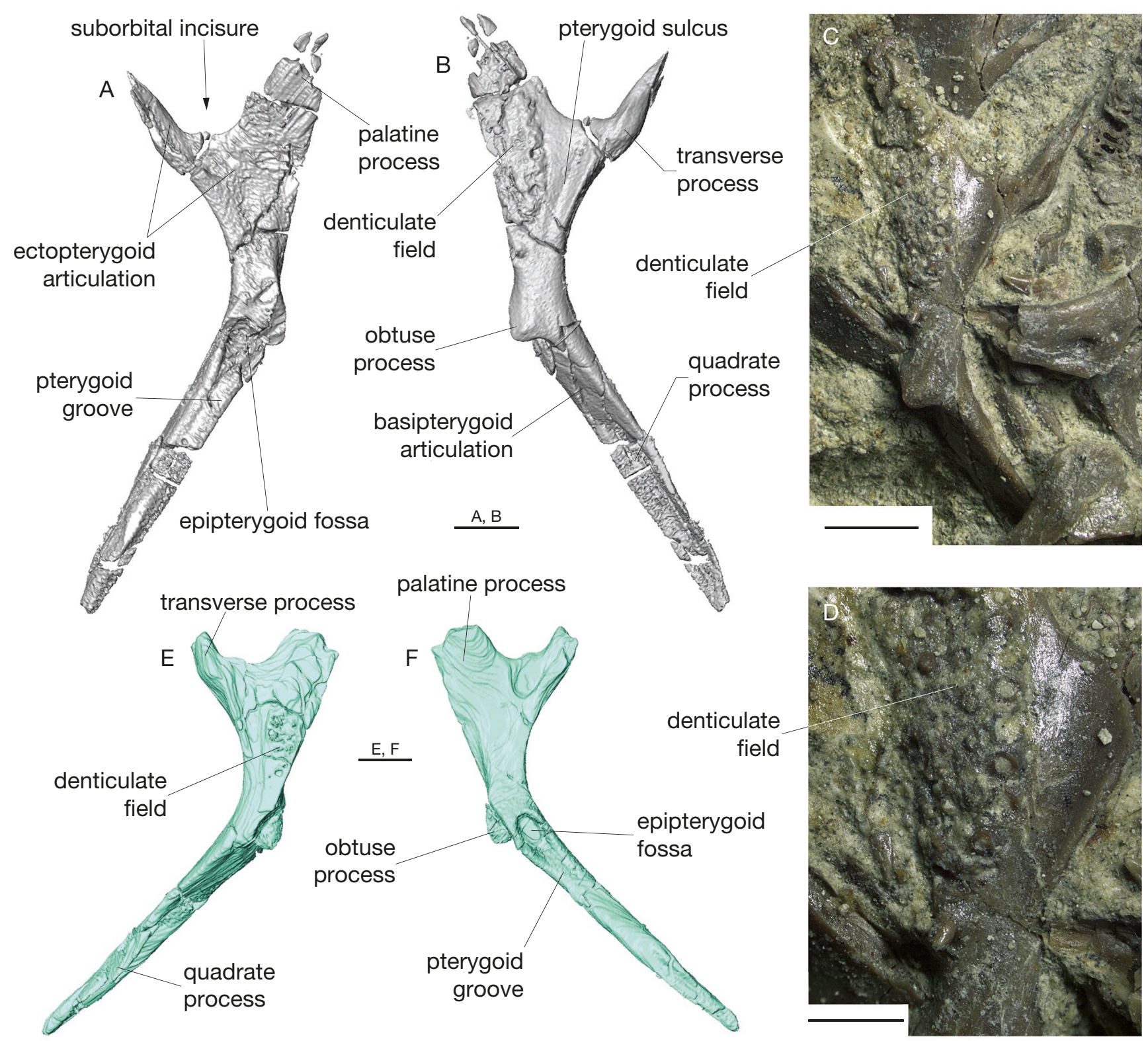

FIG. 9. - Ophisaurus acuminatus Jörg, 1965, SMNK-PAL.8561: A-C, left pterygoid in dorsal (A) and ventral (B, C) views; D, detail of its denticulate field of the same pterygoid; E, F, virtual 3D models of right pterygoid in ventral $(\mathbf{E})$ and dorsal $(\mathbf{F})$ views. Scale bars: A-C, E, F, 2 mm; D, $1 \mathrm{~mm}$.

\section{Surangular and articular}

The left and right surangulars and a small remnant of the left articular are preserved (Figs 1; 2A; 11C, F, G). Only the left surangular is partially articulated with the neighbouring bones of the mandible (Fig. 11F, G). The surangular is an elongate and massive element forming the posterodorsal portion of the lower jaw. In the anterodorsal region and close posterior to the dentary, the dorsolateral surface of the bone is pierced by a large anterior surangular foramen (Figs 1; 11F). On the medial wall of the surangular, a deep mandibular/adductor fossa is present immediately posterior to the posterior process of coronoid articulation. (Fig. 11G). The posterior portions of both mandibles are broken, but the impression of the left posterior portion of the mandible is well-preserved. Here, a small remnant of the articular is preserved (Figs 1; 2A; 11C).
TEETH

There are four elements bearing dentition: dentary, maxilla, pterygoid and palatine. The denticles on the palatine are not preserved, but a row of rounded pits indicates their presence (Fig. 8A). The denticles on the pterygoid are arranged in four longitudinal rows. The denticles are conical and pointed. Their apices are posteriorly curved. The denticles lying in the most lateral row are the largest (Fig. 9B-E).

Implantation of the marginal teeth is pleurodont. The teeth are large, well exposed over the dorsal crest which supports them laterally (Figs 1A; 7A-D; 11A-C, F, G; 12), There are 14 tooth positions in the maxilla and 15 tooth positions in dentary. They are conical and curved distally. Their tips are pointed. The mesial and distal cutting edges are well developed (Figs 11A, C; 12). The mesial surfaces of 


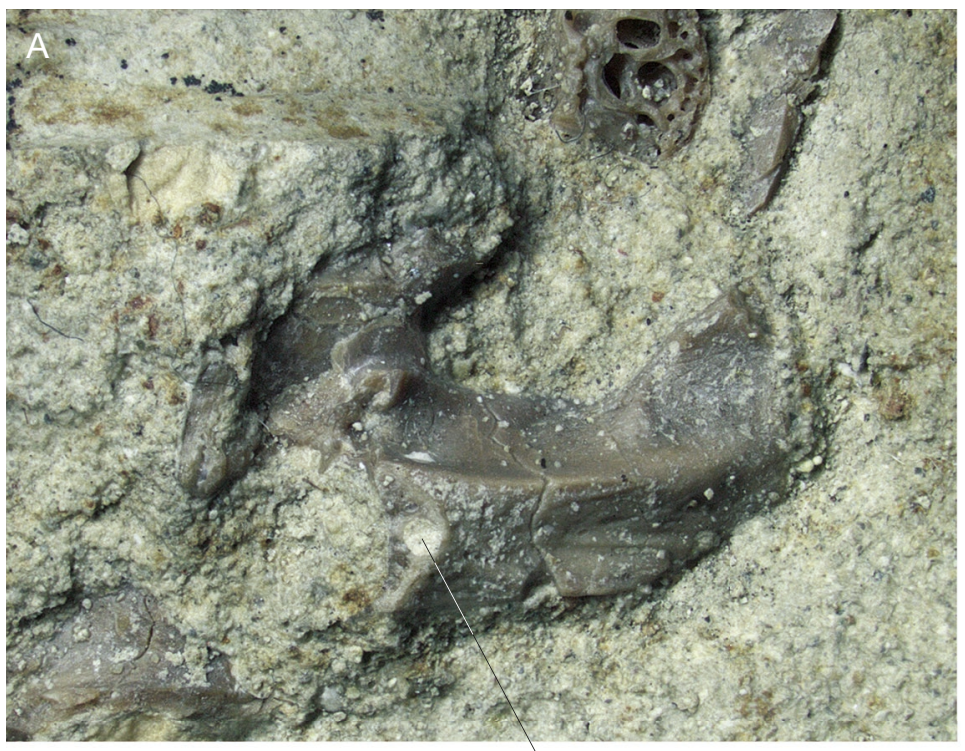

lateral semicircular canal

vagus foramen

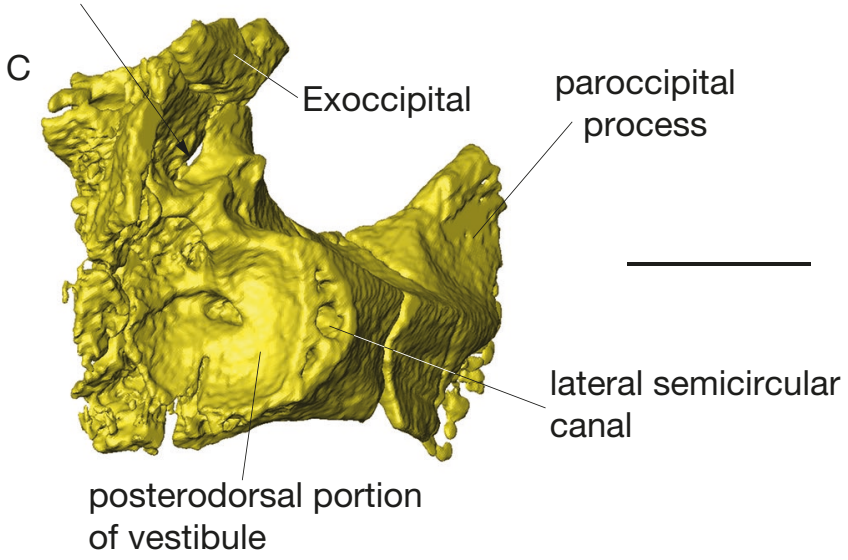

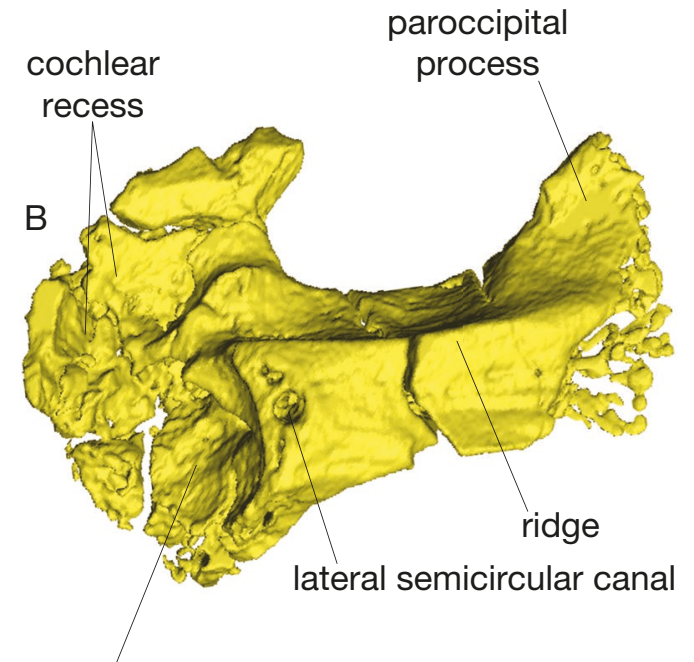

posterodorsal portion of vestibule

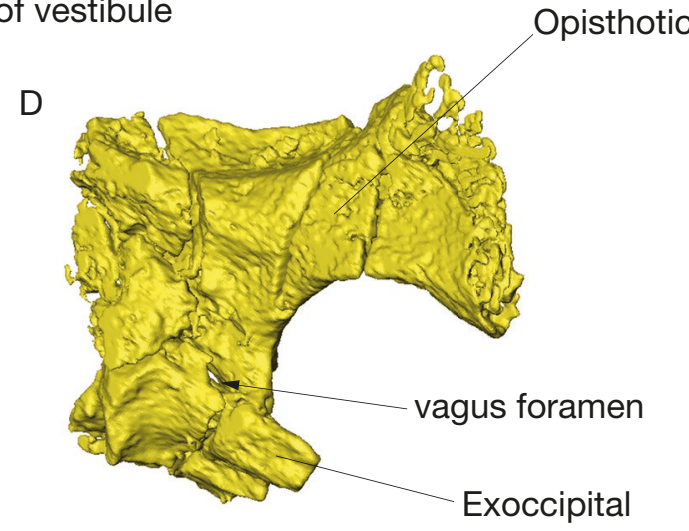

FIG. 10. - Ophisaurus acuminatus Jörg, 1965, SMNK-PAL.8561: A-D, photograph (A) and virtual 3D models (B-D) of right fused exoccipital and opisthotic in anterolateral (A, B), anterior (C) and posterolateral (D) views. In A-C, fused exoccipital and opisthotic are dorsoventrally turned up. Scale bars: 2 mm.

apices are smooth. The tooth bases are mesiodistally broad. The largest maxillary teeth are present in the mid-region of the tooth row what corresponds to the size of teeth in the dentary.

Remarks. The marginal teeth of $O$. acuminatus are morphologically similar to those in some extant species of Ophisaurus, like O. koellikeri, however, in contrast to O. koellikeri, the internal surface of their apices is not striated in $O$. acuminatus. The teeth of $O$. acuminatus are very similar to those designated as Anguinae indeterminate 1 from early Miocene deposits of North Bohemia (Czech Republic) (Klembara 2015). The teeth of Anguinae indeterminate 1 are posteriorly curved, pointed and have well-developed anterior and posterior cutting edges. The medial surface of their apices is not striated (Klembara 2015: figs 5, 6A). The teeth in $O$. acuminatus are also similar to those in the Oligocene Ophisaurus roqueprunensis Augé, 1992 (Augé \& Smith 2009).

\section{OSTEODERMS}

Almost all osteoderms are incompletely preserved (Figs 1; 14). Some of them are directly associated with the holotype being embedded together in the sediment. Additional ten osteoderms are preserved as isolated elements (Fig. 14). Unfortunately, the internal surface of the isolated osteoderms is not accessible, because the osteoderms had been fixed by the glue on a sheet of paper in the past. The osteoderms studied here can be divided into two morphotypes.

The first morphotype is represented by a slender, flat and more oval (or elliptical) osteoderms (Fig. 14A-E). This morphotype has no longitudinal keel and the external side bears a very large gliding surface. The lateral bevel appears to be highest close to this surface. Posteriorly located external surfaces of the osteoderms are ornamented. The ornamentation consists of short ridges, grooves, tubercles and shallow pits. The ridges have a vaguely radial orientation from the anterior portion of the osteoderm. The internal surface is smooth and bears several foramina (Fig. 14B). 


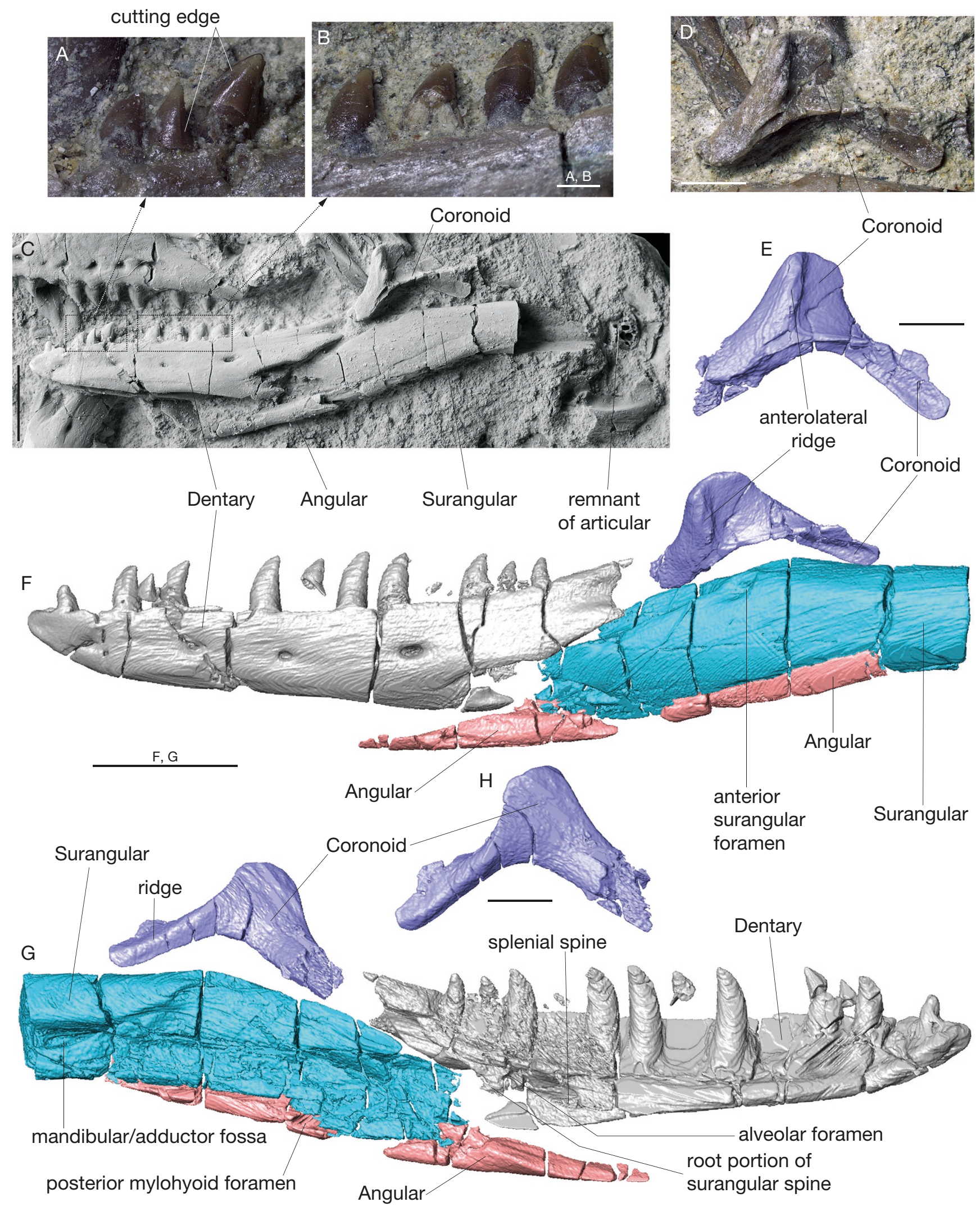

FIG. 11. - Ophisaurus acuminatus Jörg, 1965, SMNK-PAL.8561: A-G, photographs (A-D) and virtual 3D models (E-H) of left lower jaw elements and teeth in lateral (A-F) and medial (G, H) views. Scale bars: A, B, $0.5 \mathrm{~mm}$; D, E, H, 2 mm; C, F, G, $5 \mathrm{~mm}$. 


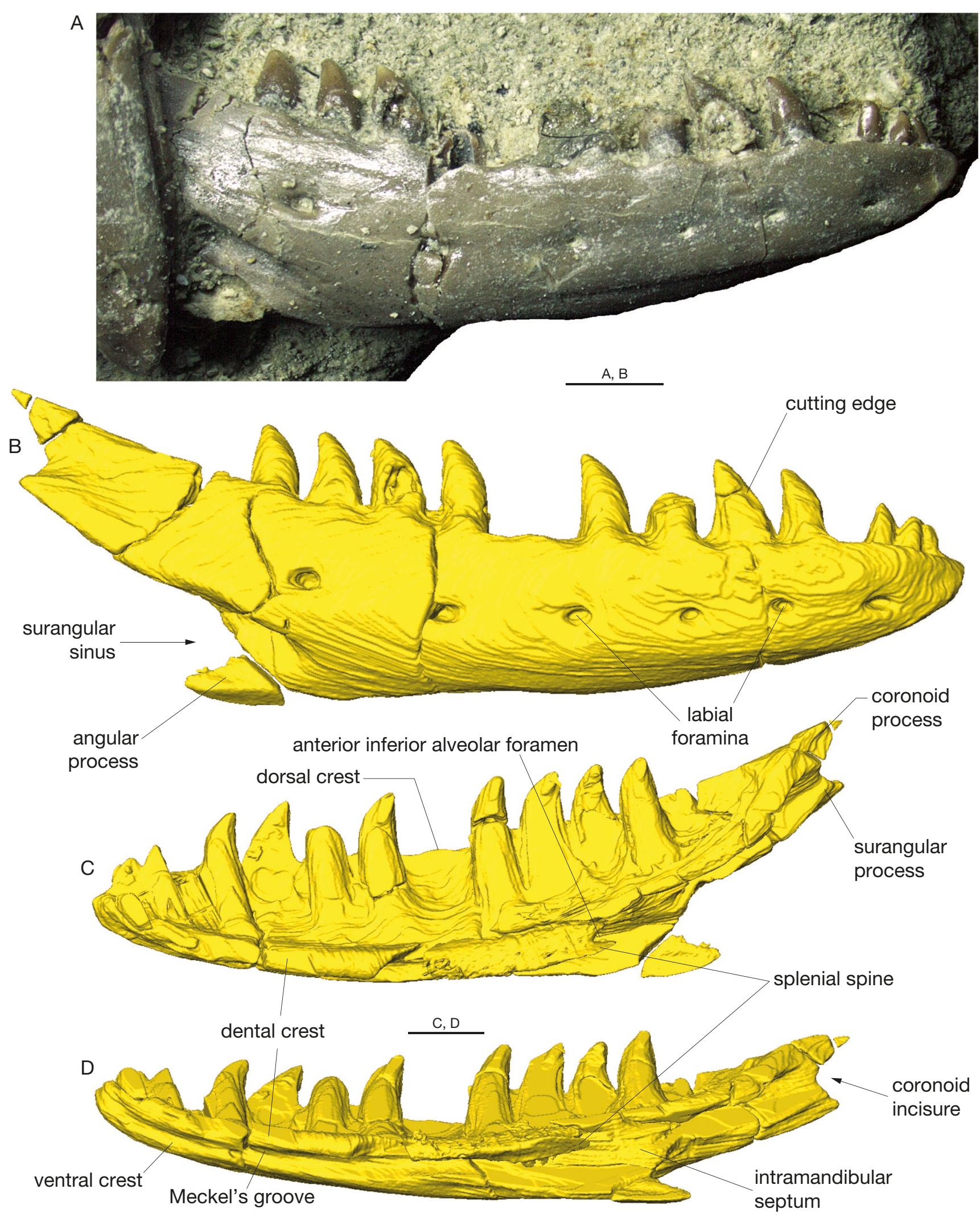

FIG. 12. - Ophisaurus acuminatus Jörg, 1965, SMNK-PAL.8561: A, photograph; C, D, virtual 3D models of right dentary in lateral (A, B), medial (C) and ventromedial (D) views. Scale bar: $2 \mathrm{~mm}$. 

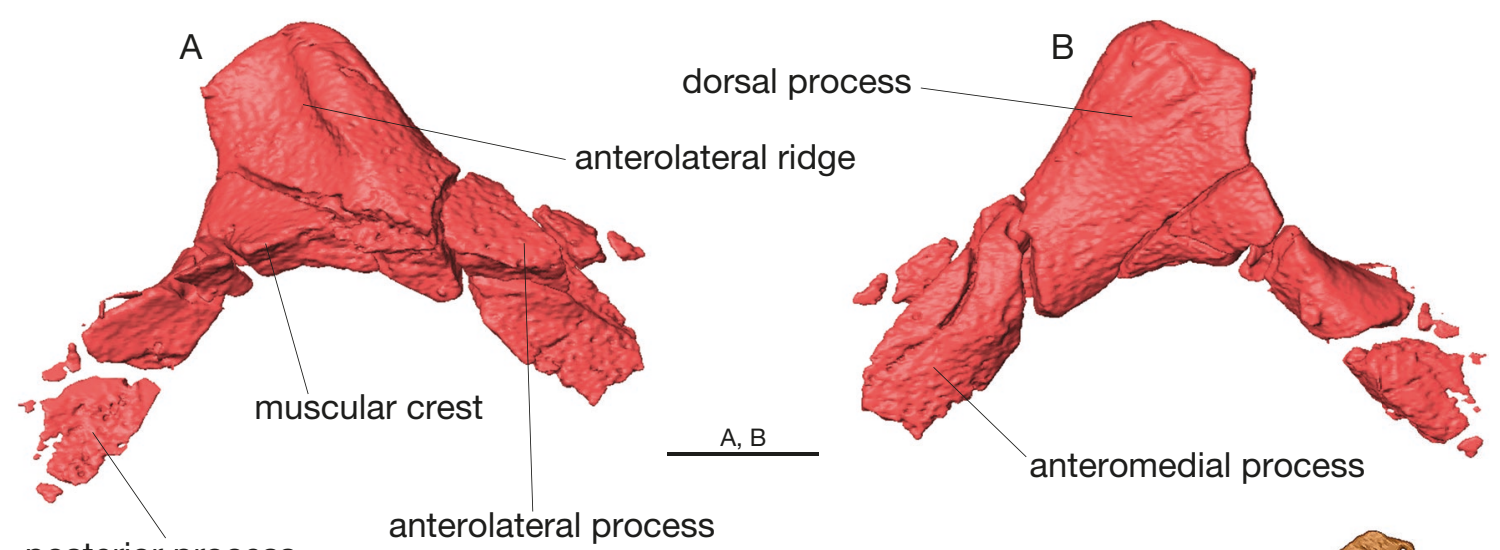

posterior process

anterolateral process
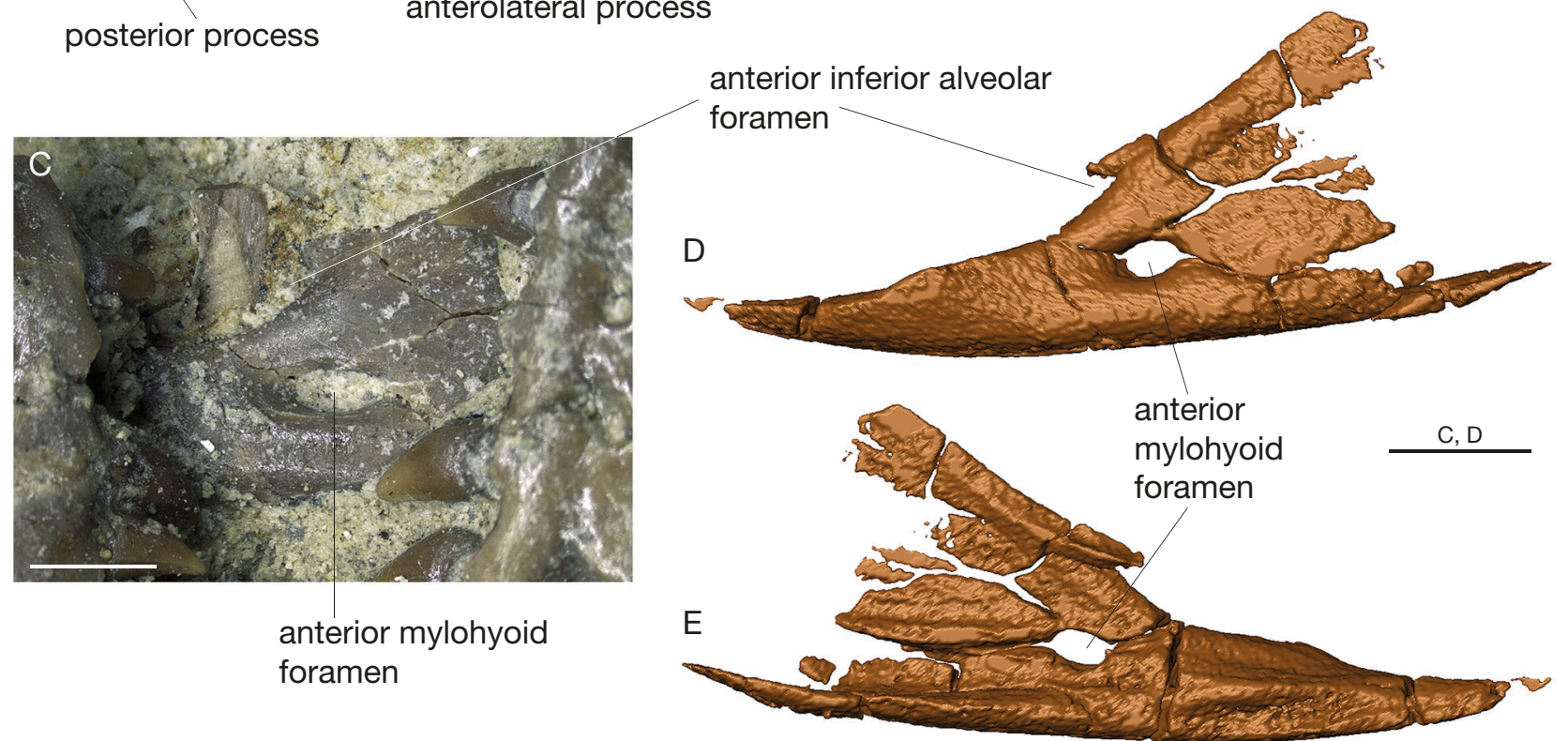

FIG. 13. - Ophisaurus acuminatus Jörg, 1965, SMNK-PAL.8561: A, B, right coronoid in lateral (A) and medial (B) views; C-E, photograph (C) and virtual 3D models (D, E) of right splenial in lateral (C, D) and medial (E) views. Scale bars: A, B, D, E, $2 \mathrm{~mm}$; C, $1 \mathrm{~mm}$.

Osteoderms of the second morphotype are roughly rectangular (Fig. 14F, G). This type possesses a low medial keel, as well as the ornamented surface and lateral bevel. These osteoderms bear a similar type of ornamentation as that in the first morphotype.

Remarks. This type of morphology of osteoderms corresponds to that of Ophisaurus (e.g., Čerňanský \& Klembara 2017). The presence of two morphotypes most likely reflects the position of the osteoderms in the different portion of the body armour.

\section{COMPARISONS AND DISCUSSION}

Jörg (1965) made comparisons of the individual bones of O. acuminatus mostly with three anguine species of Pseudopus: P. laurillardi, P. pannonicus and P. apodus. In the light of these comparisons Jörg (1965) considered the following features as distinguished for $O$. acuminatus: 1) assymetric, pointed crowns; 2) presence of cutting edges on crowns; 3) slightly posteriorly curved teeth; and 4) relatively large spaces between individual teeth. The morphology of the teeth of $O$. acuminatus is really very different from that of all three species of Pseudopus, because the posterior teeth of Pseudopus are stout, rod-like, their apices are blunt and striated (Klembara et al. 2014). However, none of these four characters represents a distinguished feature of O. acuminatus (see also "TeEtH" above).

The species $O$. acuminatus differs from all living and fossil species of Ophisaurus (Klembara \& Rummel 2018) by two autapomorphic features and the combination of one feature:

1) The presence of a distinct ornamentation of the nasal bones. The ornamentation present on the nasal bones consists of robust ridges and deep grooves, thus it is exceptionally distinct among extinct or extant Ophisaurus species, and it is more reminiscent to that in Pseudopus (Klembara 2012). Comparing the grade of the development of ridges and grooves of the equivalent size of ornamentation of the nasal bone of $O$. acuminatus with that in any other species of Ophisaurus, the distinctness of the ornamentation in O. acuminatus is evident (Fig. 4A, C-E; Klembara 2012: fig. 3).

2) Straight posterior margins of posterior ornamented shields of nasals. Among the fossil species of Ophisaurus, the nasal is preserved only in one juvenile specimen of the middle Miocene 

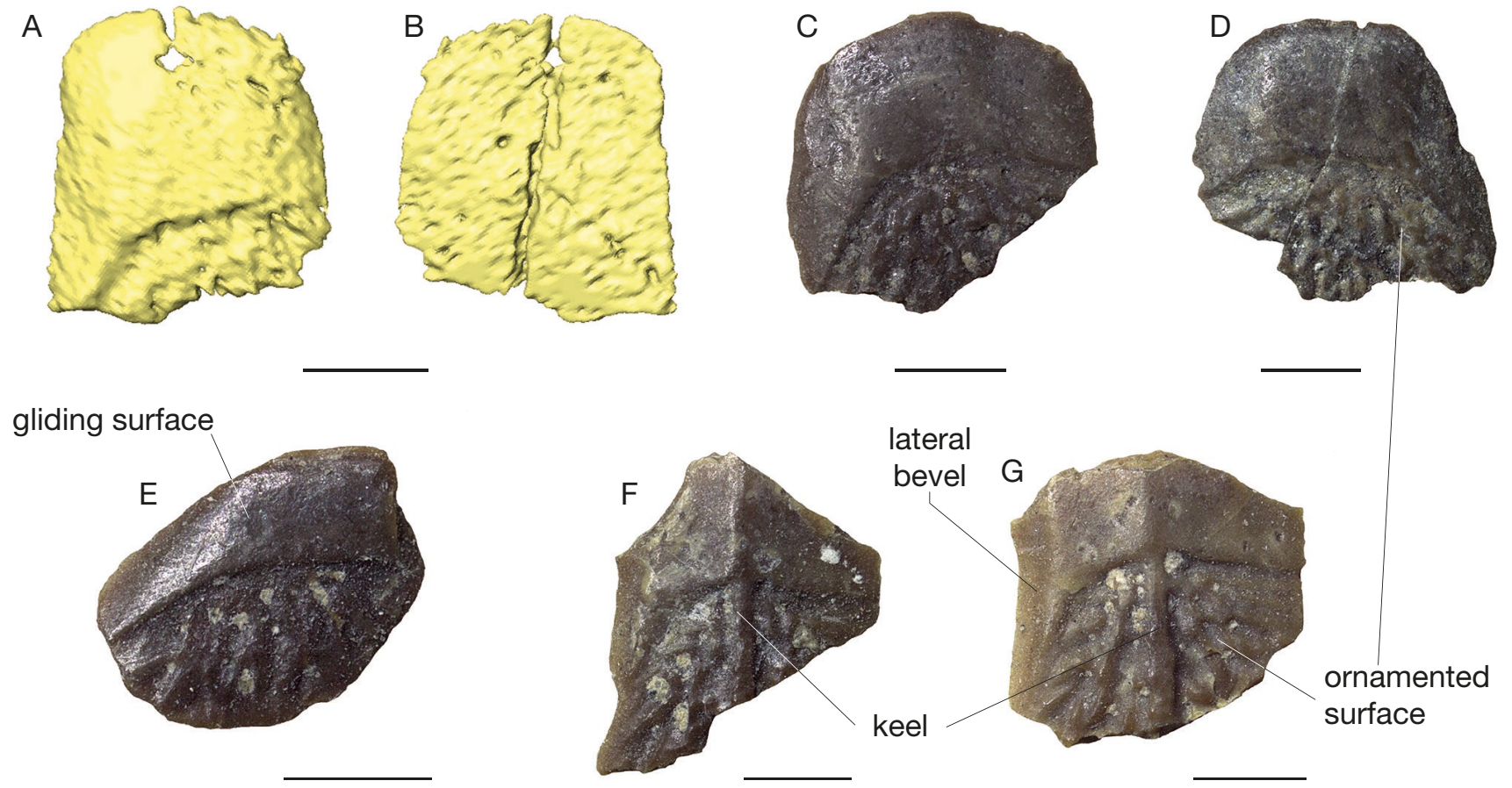

FIG. 14. - Ophisaurus acuminatus Jörg, 1965, SMNK-PAL.8610: A-G, osteoderms in external (A, C-G) and internal (B) views. Scale bars: 1 mm.

O. holeci from Germany (Čerňanský \& Klembara 2017). The nasal of $O$. holeci is of trapezoid shape. Its ornamented surface is distinct and bears distinct pits of various size. In large specimens of Recent Ophisaurus, one pair of anterior and one pair of posterior ornamented shields of nasal are present (Fig. 4D, E). However, the size, shape and course of sutures with neighbouring bones differ from the conditions present in $O$. acuminatus. In $O$. attenuatus and $O$. ventralis, the anterior shields are larger than posterior shields; this is in contrast to the conditions in O. acuminatus (Fig. 4A, D, E). In both these extant species, the posterior portions of the posterior shields are mediolaterally narrowed and the triangular space between them is occupied by the anteromedially extending nasal processes of the frontal (Fig. 4D, $\mathrm{E})$. In O. acuminatus, the posterior margins of the posterior nasal ornamented shields are mediolaterally almost straight, thus there is no space between them. The nasal processes of frontal underlie the posteromedial corners of the nasals; two fragments probably representing the nasal processes of frontals present in this region indicate this anatomical condition (Fig. 4B).

3) In Ophisaurus acuminatus, the anterior margin of the anterior mylohyoid foramen lies slightly posterior to the level of the posterior margin of the anterior inferior alveolar foramen (Fig. 13C-E). In Recent species of Ophisaurus, the anterior mylohyoid foramen lies distinctly posterior to the posterior margin of the anterior inferior alveolar foramen (Klembara et al. 2014: fig. 8). Instead, in $O$. acuminatus the position of the anterior mylohyoid foramen is similar to what can be seen in $A$. fragilis and $O$. attenuatus (Klembara et al. 2014: fig. 8). However, the morphology of teeth in $O$. attenuatus is completely different to that in $O$. acuminatus (Klembara et al. 2014: fig. 8F and Figs 11,12 in this paper). In P. apodus, the anterior mylohyoid foramen lies at the level of the posterior margin of the anterior inferior alveolar foramen (Klembara et al. 2014: figs 7, 8A). In $O$. acuminatus, the posterior wall of the anterior inferior alveolar foramen is formed completely by the splenial. Here, the splenial forms an anteriorly extending process forming a posterodorsal margin of the anterior inferior alveolar foramen. Besides $O$. acuminatus, such process is present only in $O$. harti (Klembara et al. 2014: fig. 8).

\section{REMARKS ON ECOLOGY}

Although members of Ophisaurus are absent in modern ecosystems of Europe their fossils are quite abundant in the Miocene deposits. O. acuminatus represents one of the last records of Ophisaurus from the territory of Central Europe. To interpret the palaeoecology and natural environment of $O$. acuminatus, the presence of plants at the locality of $O$. acuminatus is one of the key factors. The plant remains in Höwenegg are relatively abundant, but they represent only a little diversified taphocoenosis, where the dominant taxon is the Mediterranean genus Celtis. The plant community is similar to other middle and upper Miocene communities of central Europe (see Gregor 1982). This deciduous flora shows a warm-temperate character, which is indicative of warm mesophytic forests with nominal seasonality (Gregor 1982; Bernor et al. 1988). Paleoecological interpretations of Tobien (1986), which are based on the mammalian asemblage, support the reconstruction of the Höwenegg paleohabitat suggested by Gregor (1982) and later by Bernor et al. (1988). The paleohabitat of this locality was most likely part of the subtropical mesophytic forests that covered large parts of central and western Europe, central Asia and southern China during the Vallesian Period (Bernor et al. 1988). On the basis of the current knowledge, $O$. acuminatus appears to be most likely a forest species rather than occupying open space environments. 


\section{Acknowledgements}

We are grateful to Dr E. Frey (State Museum for Natural History, Karlsruhe, Germany) for the loan of the specimen of Ophisaurus acuminatus for the present study. For the CT scanning of this specimen, we thank K. Mahlow (Museum für Naturkunde, Berlin). The photographs of the specimen coated with ammonium chloride were performed by A. Vögel (Senckenberg Research Institute, Frankfurt). We also thank Salvador Bailon and Maxime Lasseron (Muséum national d'Histoire naturelle) who helped to improve a previous version of the manuscript. This project was supported by the Scientific Grant Agency of Ministry of Education of Slovak Republic and Slovak Academy of Sciences, Grant number $1 / 0209 / 18$.

\section{REFERENCES}

AugÉM. 1992. - Une espèce nouvelle d'Ophisaurus (Lacertilia,Anguidae) de l'Oligocène des phosphorites du Quercy. Révision de la sousfamille des Anguinae. Paläontologische Zeitschrift 66: 159-175. https://doi.org/10.1007/BF02989486

Augé M. \& SMITH R. 2009. - An assemblage of early Oligocene lizards (Squamata) from the locality of Boutersem (Belgium), with comments on the Eocene-Oligocene transition. Zoological Journal of the Linnean Society 153: 148-170. https://doi. org/10.1111/j.1096-3642.2008.00435.x

Blain H. A., Agustí J., López-Garcia J. M., Haddoumi H., Aouraghe H., Hammouti K. E., Pérez-Gonzáles A., Chacón M. G. \& SALA R. 2013. - Amphibians and squamate reptiles from the Late Miocene (Vallesian) of Eastern Morocco (Guefait-1, Jerada Province). Journal of Vertebrate Paleontology 33: 804-816. https://doi.org/10.1080/02724634.2013.740541

Bernor R. L., Kovar-Eder J., Lipscomb D., Rögl F., Sen S. \& Tobien H. 1988. - Systematics, stratigraphic and paleoenvironmental contexts of first-appearing Hipparion in the Vienna Basin, Austria. Journal of Vertebrate Paleontology 8: 427-452. https://doi.org/10.1080/02724634.1988.10011729

Bernor R. L., Tobien H., HayeK L. A. C. \& Mittmann H. W. 1997. - Hippotherium primigenium (Equidae, Mammalia) from the late Miocene of Höwenegg (Hegau, Germany). Andrias 10: $1-230$.

Boulenger G. A. 1899. - On a collection of reptiles and batrachians made by Mr. J. D. La Touche in N. W. Fokien, China. Proceedings of the Zoological Society of London 1899: 159-172. https://www.biodiversitylibrary.org/page/30951172

BÖHME M. \& Ilg A. 2003. - FosFARbase. Available at: http:// www.wahrestaerke.com

ČERŇANSKÝ A. \& Klembara J. 2017. - A skeleton of Ophisaurus (Squamata: Anguidae) from the middle Miocene of Germany, with a revision of the partly articulated postcranial material from Slovakia using micro-computed tomography. Journal of Vertebrate Paleontology 37: e1333515. https://doi.org/10.1080/02724634.2017.1333515

COPE S. F. 1880. - On the zoological position of Texas. Bulletin of the United States National Museum 17: 3-51. https://www. biodiversitylibrary.org/page/7529362

Cope E. D. 1900. - The crocodilians, lizards and snakes of North America. Annual Reports of the United States National Museum 1898: 153-1270. https://repository.si.edu/handle/10088/29934

DaUdin F.-M. 1803. - Histoire naturelle des Reptiles. Deterville, Paris, 8 vols.

Delfino M., Bailon S. \& Pitruzzella G. 2011. — The Late Pliocene amphibians and reptiles from "Capo Mannu D1 Local Fauna” (Mandriola, Sardinia, Italy). Geodiversitas 33: 357-382. https://doi.org/10.5252/g2011n2a10
FÜrbringer M. 1900. — Zur Vergleichenden Anatomie Brustschulterapparatus und der Schultermuskeln. Janaische Zeitschrift für Naturwissenschaft 34: 215-718.

GAUDANT J. 2015. - Re-examination of the upper Miocene freshwater fish fauna from Höwenegg (Hegau, Germany). Swiss Journal of Palaeontology 134: 117-127. https://doi.org/10.1007/ s13358-015-0073-2

GiERSCH S., MunK W. \& Ziegler R. 2010. — The first record of a beaver - Trogontherium (Euroxenomys) minutum - in the Höwenegg fauna (Miocene, southern Germany). Palaeodiversity 3: 235-239.

GRAY J. E. 1825. - A synopsis of the genera of reptiles and amphibia, with a description of some new species. Annals of Philosophy, London 10: 193-217. https://www.biodiversitylibrary.org/page/2531387

GraY J. E. 1845. - Catalogue of the Specimens of Lizards in the Collection of the British Museum. Trustees of die British Museum/ Edward Newman, London: xxvii + 289 p. https://doi.org/10.5962/ bhl.title. 5499

Gregor H. J. 1982. - Die jungtertiären Floren Süddeutschlands. Paläokarpologie, Phytostratigraphie, Paläoökologie, Paläoklimatologie. Enke, Stuttgart, 278 p.

GÜNTHER A. 1873. - Description of a new Saurian (Hyalosaurus) allied to Pseudopus. Annals and Magazine of Natural History 11: 351. https://doi.org/10.1080/00222937308696828

JÖRG E. 1954. — Die Schichtenfolge der Fossilfundsttelle Höwenegg (Hegau) (Pontische Mergel und Tuffite der Oberen Süsswassermolasse. Jahresberichte und Mitteilungen des Oberrheinischen Geologischen Vereins (N.F.) 35: 67-87.

JÖRG E. 1965. — Ophisaurus acuminatus nov. spec. (Anguidae, Rept.) von der pontischen Wirbeltier-Fundstätte Hewenegg Hegau. Beiträge zur Naturkundlichen Forschungen in SW-Deutschland 24: 21-30.

Jörg E., Rest H. \& Tobien H. 1955. - Die Ausgrabungen an der jungtertiären Fossilfundstatte Höwenegg/Hegau 1950-1954. Beiträge zur Naturkundlichen Forschung in Südwestdeutschland 14: 3-21.

Klembara J. 1981. — Beitrag zur Kenntniss der Subfamilie Anguinae. Acta Universitatis Carolinae - Geologica 2: 121-168.

Klembara J. 1986. - New finds of the genus Ophisaurus (Reptilia, Anguidae) from the Miocene of Western Slovakia (Czechoslovakia). Acta Universitatis Carolinae - Geologica (špinar vol.) 2: 187-203.

Klembara J. 2012. - A new species of Pseudopus (Squamata, Anguidae) from the early Miocene of North-West Bohemia (Czech Republic). Journal of Vertebrate Paleontology 32: 854-866. https://doi.org/10.1080/02724634.2012.670177

Klembara J. 2015. - New finds of anguines (Squamata, Anguidae) from the Early Miocene of North-West Bohemia (Czech Republic). Paläontologische Zeitschrift 89: 171-195. https://doi. org/10.1007/s12542-014-0226-4

Klembara J., BöHme M. \& Rummel M. 2010. - Revision of the anguine lizard Pseudopus laurillardi (Squamata, Anguidae) from the Miocene of Europe, with comments on paleoecology. Journal of Paleontology 84: 159-196. https://doi.org/10.1666/09-033R1.1

Klembara J., Hain M., \& DobiAšOVÁ K. 2014. — Comparative Anatomy of the Lower Jaw and Dentition of Pseudopus apodus and the Interrelationships of Species of Subfamily Anguinae (Anguimorpha, Anguidae). Anatomical Record 297: 516-544. https://doi.org/10.1002/ar.22854

Klembara J., Hain M. Dobiašová K. \& Yarihin A. 2017. — Skull anatomy and ontogeny of legless lizard Pseudopus apodus (Pallas, 1775): heterochronic influences on form. Anatomical Record 300: 460-502. https://doi.org/10.1002/ar.23532

Klembara J. \& Rummel M. 2018. - New material of Ophisaurus, Anguis and Pseudopus (Squamata, Anguidae, Anguinae) from the Miocene of the Czech Republic and Germany and systematic revision and palaeobiogeography of the Cenozoic Anguinae. Geological Magazine 155: 20-44. https://doi.org/10.1017/ S0016756816000753

Kormos T. 1911. - Der pliozäne Knochenfund bei Polgárdi. Földtani Közlöni 41: 1-19. 
LARTET E. 1851. - Notice sur la colline de Sansan. Annuaire du département du Gers, Auch: 1-45.

LINNAEUS C. VON 1758. - Systema nature per regna tria nature, secundum classes, ordines, genera, species cum characteribus differentiis, synonymis, locis. Tomus I. Editio decima, reformata. Laurentii Salvii, Holmiæ, 824 p. https://doi.org/10.5962/ bhl.title. 542

LINNAEUS C. VON 1766. - Systema nature per regna tria nature, secundum classes, ordines, genera, species, cum characteribus, differentiis, synonymis, locis. Tomus I. Editio duodecima, reformata. Laurentii Salvii, Stockholm, Holmiae: 1-532. https://gallica. bnf.fr/ark:/12148/bpt6k99004c

Munk W., Bernor R. L., Heizmann E. P. J. \& Mittmann H.-W. 2007. - Excavations at the Late Miocene MN 9 (10.3 Ma) Locality of Höwenegg (Hegau), Southwest-Germany, 2004-2006. Carolinea 65: 5-13.

Oppel M. 1811. - Die Ordnungen, Familien und Gattungen der Reptilien als Prodrom einer Naturgeschichte derselben. Joseph Lindauer, München, 86 p. https://doi.org/10.5962/bhl.title.4911

Pallas P. S. 1775. - Lacerta apoda descripta. Novi commentari Academiae Scientiarum Imperialis Petropolitanae 19: 435-454. https://www.biodiversitylibrary.org/page/36977113

PALMER W. M. 1987. - A new species of glass lizard (Anguidae: Ophisaurus) from the southeastern United States. Herpetologica 43: 415-423. https://www.jstor.org/stable/3892144

RAGE J.-C. \& AugÉ M. 2010. - Squamate reptiles from the middle Eocene of Lissieu (France). A landmark in the middle Eocene of Europe. Geobios 43: 253-268. https://doi.org/10.1016/j. geobios.2009.08.002

SCHLEICH H. H. 1986. — Vorläufige Mitteilungen zur Bearbeitung der fossilen Schildkröten der Fundstelle Höwenegg. Carolinea 44: 47-50.

STEININGER F. F. 1999. - Chronostratigraphy, geochronology and biochronology of the Miocene 'European land mammal mega-zones' (ELMMZ) and the Miocene 'Mammal-zones', in RÖSSNER G. E. \& HEISSIG K. (eds), The Miocene Land Mammals of Europe. Friedrich Pfeil, Munich: 9-24.

SWISHER C. C. III 1996. - New 40Ar/39Ar dates and their contribution toward a revised chronology for the late Miocene non-marine of Europe and West Asia, in BERNOR R. L., FAHLBUSCH V. \& MitTMANN H.-W. (eds), The Evolution of Western Eurasian Neogene Mammal Faunas. Columbia University Press, New York: 271-289.

Tobien H. 1938. — Über Hipparion-Reste aus der obermiozänen Süsswassermolasse Südwestdeutschlands. Zeitschrift der deutschen geologischen Gesellschaft 90: 177-192.

TOBIEN H. 1986. — Die jungtertiaere Fossilgrabungsstaette Höwenegg in Hegau (Südwestdeutschland). Carolinea 44: 9-34.

Woodburne M. O., Theobald G., Bernor R. L., Swisher C. C., KÖNIG H. \& TobIEN H., 1996. - Advances in the Geology and Stratigraphy at Höwenegg, Southwestern Germany, in Bernor R. L., Fahlbusch V. \& MitTmann H. W. (eds), The Evolution of Western Eurasian Neogene Mammal Faunas. Columbia University Press, New York: 106-123. 